


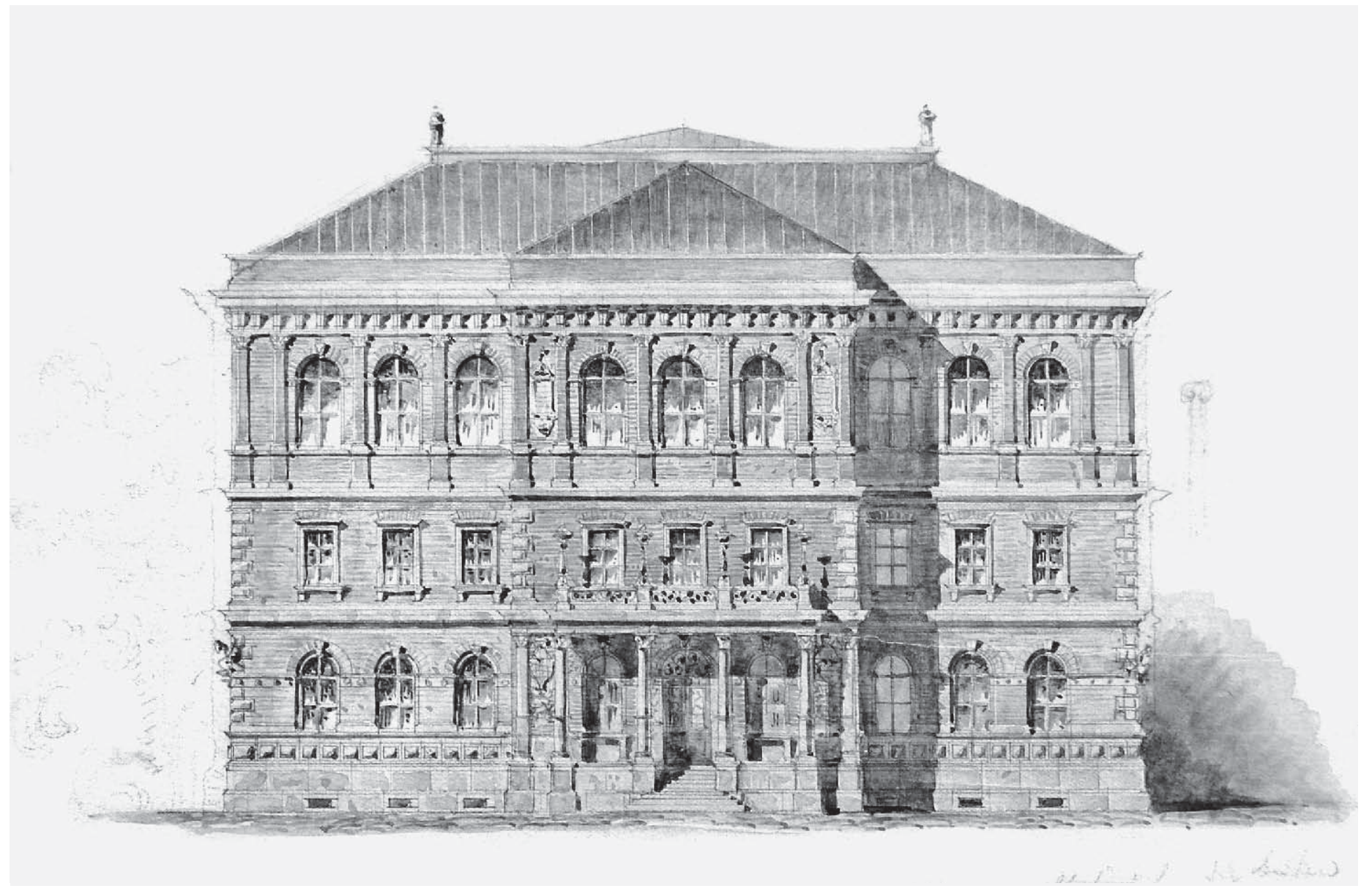

Sl. 1. F. Schmidt: Projekt Za glavno pročelje Zgrade Akademije, ArheološKog odjela Narodnoga muzeja I Galerije Slika u Zagrebu, 1877., Kolorirana Varijanta

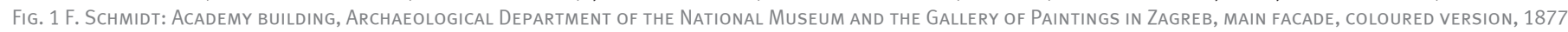




\section{DRAGAN DAMJANOVIĆ}

SVEUČILIŠTE U ZAGREBU

FILOZOFSKI FAKULTET

ODSJEK ZA POVIJEST UMJETNOST

HR - 10000 ZAGREB, IVANA LUČICA 3

ddamjano@ffzg.hr; dragan.damjanovic@gmail.com

IZVORNI ZNANSTVENI ČLANAK

https://doi.org/10.31522/p.27.1(57).2

UDK 72.035 F. SCHMIDT (497.5 ZAGREB)"18"

TEHNIČKE ZNANOSTI / ARHITEKTURA I URBANIZAM

2.01.04. - POVIJEST I TEORIJA ARHITEKTURE I ZAŠTITA GRADITELJSKOG NASLIJEĐA

HUMANISTIČKE ZNANOSTI / POVIJEST UMJETNOSTI

6.09.01. - POVIJEST I TEORIJA LIKOVNIH UMJETNOSTI, ARHITEKTURE, URBANIZMA I VIZUALNIH KOMUNIKACIJA

ČLANAK PRIMLIEN / PRIHVAĆEN: 15. 4. 2019. / 17. 6. 2019.
UNIVERSITY OF ZAGREB

FACULTY OF HUMANITIES AND SOCIAL SCIENCES

DEPARTMENT OF ART HISTORY

CROATIA - 10000 ZAGREB, I. LUČICA 3

ddamjano@ffzg.hr; dragan.damjanovic@gmail.com

ORIGINAL SCIENTIFIC PAPER

https://doi.org/10.31522/p.27.1(57).2

UDC 72.035 F. SCHMIDT (497.5 ZAGREB)"18"

TeChNical SCIEnces / ARChitecture And URban Planning

2.01.04. - HISTORY AND THEORY OF ARCHITECTURE

and Preservation of the Built Heritage

HUMANITIES / ART HISTORY

6.09.01. - History AND THEORY OF Fine ARTS, ARCHITECTURE, Urban Planning and Visual Communication

Article Received / Accepted: 15. 4. 2019. / 17. 6. 2019.

\title{
ProjeKtiRANJe PALAČE HRVATSKE AKADEMIJE ZNANOSTI I UMJETNOSTI U ZAGREBU 1875.-1877. RENESANSA RENESANSE U HRVATSKOJ ARHITEKTURI
}

\author{
Designing the Palace of the CroAtian ACADEMy \\ OF SCIENCES AND ARTS IN ZAGREB (1875-1877) \\ Renaissance of the Renaissance in Croatian ArChitecture
}

HISTORICIZAM

HRVATSKA AKADEMIJA ZNANOSTI I UMJETNOSTI

KRŠNJAVI, ISO

NEORENESANSA

SCHMIDT, FRIEDRICH

STROSSMAYER, JOSIP JURAJ

\author{
HISTORICISM \\ Croatian Academy of SCiences and Arts \\ KRŠNJAVI, ISO \\ NEO-RENAISSANCE \\ SCHMIDT, FRIEDRICH \\ STROSSMAYER, JOSIP JURAJ
}

Članak govori o projektima bečkog arhitekta Friedricha Schmidta za palaču Hrvatske akademije znanosti i umjetnosti u Zagrebu. Zbog problema oko izbora lokacije i nedostatka sredstava Schmidt je izradio tri projekta za ovu zgradu -1875., 1876. i 1877. U procesu njihove izrade ključnu su ulogu imali biskup Josip Juraj Strossmayer, inicijator izgradnje palače, predsjednik Akademije Franjo Rački i prvi hrvatski povjesničar umjetnosti Iso Kršnjavi.
This article focuses on the designs of the Viennese architect Friedrich Schmidt for the palace of the Croatian Academy of Sciences and Arts in Zagreb. Due to some problems with site selection and lack of budget, Schmidt produced three design versions $(1875,1876$ and 1877$)$. The key figures in this process were Bishop Josip Juraj Strossmayer, the initiator of palace construction, Franjo Rački, president of the Academy, and Iso Kršnjavi, the first Croatian art historian. 


\section{UVOD}

\section{INTRODUCTION}

redišnja ${ }^{1}$ palača Jugoslavenske (danas Hrvatske) akademije znanosti i umjetnosti na Trgu Nikole Šubica Zrinskog u Zagrebu jedno je od najvažnijih djela javne arhitekture historicizma u Hrvatskoj uopce. ${ }^{2}$ Svojom monumentalnošcu uvelike je pripomogla urbanizaciji dijela Zagreba u kojem je podignuta istočnoga kraka takozvane Zelene potkove. A svojim arhitektonskim rješenjem predstavlja jedno od prvih djela visokoga historicizma u hrvatskoj arhitekturi (SI. 1.).

S obzirom na ulogu koju su u njenoj gradnji imali biskup Josip Juraj Strossmayer, kanonik Zagrebačke nadbiskupije, povjesničar i predsjednik Akademije Franjo Rački, prvi hrvatski povjesničar umjetnosti Iso Kršnjavi te arhitekti Friedrich Schmidt i Herman Bollé, razumljivo je da je izgradnja ove građevine privlačila interes istraživača od vremena kad je sagrađena do danas. ${ }^{3}$ Nastavljajuci se na dosadašnje istraživače, namjera je ovoga teksta pokazati kako je biskup Strossmayer zamislio i oblikovao ideju o arhitektonskom rješenju ove zgrade i analizirati dosad dijelom nepoznate projekte za palaču bečkog arhitekta Friedricha Schmidta, kojih se dio čuva u ostavštini tog arhitekta u Bečkom gradskom muzeju (Wienmuseum) ${ }^{4}$, a dio u privatnoj zbirci g. Jure Gašparca u Zagrebu. Istraživanjem se pokazalo kako je prije nastanka izvedbenoga projekta Schmidt izradio najmanje tri projekta za palaču, kojih je dio bio izveden u više različitih varijanti.

\section{BISKUP STROSSMAYER, PALAČA AKADEMIJE I IDEJA O PODIZANJU 'UKUSA' U ARHITEKTURI ZAGREBA I HRVATSKE}

\section{BISHOP STROSSMAYER, ACADEMY PALACE, AND THE IDEA OF RAISING THE LEVEL OF 'TASTE' IN THE ARCHITECTURE OF ZAGREB AND CROATIA}

Zahvaljujuci očuvanosti korespondencije biskupa Josipa Jurja Strossmayera, kao i brojnim člancima koje je objavljivao 1870-ih i početkom 1880-ih, kada je bio na vrhuncu svoje djelatnosti na polju umjetnosti i kulture, može se uvelike rekonstruirati biskupov odnos prema suvremenoj arhitekturi, koji ce odigrati ključnu ulogu u oblikovanju ideje o stilskom i u cjelini arhitektonskom rješenju palače Akademije u Zagrebu te o ulozi koju je trebala imati u arhitekturi Hrvatske i Zagreba.

Monumentalnost palače odraz je ponajprije Strossmayerova uvjerenja da ce monumentalna arhitektura pripomoći razvoju ukusa u narodu. Kao što je u svoje tekstove o freskama đakovačke katedrale, o potrebi restauracije zagrebačke katedrale, a često i u propovijedi, uključivao didaktičke pasuse koji su trebali usmjeravati suvremenike - na prvome mjestu svećenstvo, ali i ostale naručitelje umjetničkih djela, te vjernike opcenito - kako se trebaju ponašati, tako je bio uvjeren i da ce realizirane zgrade, budu li visoke kvalitete, potaknuti svojevrsnu daljnju renesansu hrvatske arhitekture i umjetnosti, dok bi one lošije kvalitete taj ukus kvarile.

Opisujuci tako jednu od najranijih realiziranih fresaka u đakovačkoj katedrali Isus liječi bolesne i nemocne slikara Alexandera Maximiliana Seitza 1874. godine Strossmayer upucuje poruku svojim čitateljima da obrate pozornost na zgradu romanskoga sloga s peristilom koja je prikazana u pozadini: „Opetujemo, da nam je drago i takovih sgrada u naših slikah vidjeti, da se i tiem boljemu ukusu priuči naš narod, jer žalibože, sve štogod se u nas il crkvenih il civilnih sgrada gradi, tako je

1 Ovaj je rad financirala Hrvatska zaklada za znanost projektom IP-2018-01-9364 Umjetnost i drżava u Hrvatskoj od prosvjetiteljstva do danas.

$2 U$ ovome tekstu koristit ce se primarno termin $\mathrm{Hr}$ vatska akademija znanosti i umjetnosti jer je riječ o suvremenom nazivu institucije koja je udomljena u palači na Zrinskom trgu 7, te kako se ne bi stvarala zabuna među citateljima korištenjem nekoliko različitih termina. S obzirom na dużinu imena institucije, ono se najcešce navodi u skracenom obliku - Akademija.

3 AntOlec, 1882: 2-3; HORVAT, 1898: 180-184; KRŠNJAVI, 1917: 166-171; KNOLL, 1922: 7-20; HORVAT, 1925: 214-227; TARTAGLIA KeLEMEN, 1973: 169-171; CVITANOVIC, 1978: 131-132; DOBRONIC, 1983: 350; MARUŠEVSKI, 1986: 69, 111-113; KNEŻEVIĆ, 1994: 35-46; KNEŻEVIĆ, 1996: 54-66, 439-441; POPOVĆAK, VANDURA, 2006: 28-30; DULIBIC, PASINI TRŻEC, 2013: 34-41; DAMJANOVIĆ, 2013: 531-535; DuLIBIC, PASINI TRZ̈EC, 2018: 272-284

4 Wienmuseum, HM, Inv. Nr. 157.080/1-30 
slabo i neukusno, da pod estetičkim vidom upravo ništ i nevriedi i ukus nam više kvari nego čisti." 5 Da se ukus prestane kvariti, nużno je, dakle, po njemu, unijeti višu razinu kvalitete i u sakralnu i u nesakralnu (civilnu) arhitekturu. Isticao je pritom kako je na području civilne arhitekture od osobite važnosti upravo javna arhitektura, i to arhitektura zgrada koje udomljuju obrazovne institucije, jer je smatrao da ce one svojim izgledom pozitivno utjecati na mladež koja se u njima obrazuje. „Dok smo na ovom svietu, i dok ovo umrlo tielo na sebi nosimo, dotle doimlje nas se i vanjski sviet. Zato sgrade, u koje mladež na nauke šaljemo, valja da su ne samo zdrave, nego da su liepe i umjetne. Tiem biva, da mladež postaje ne samo učenom, nego ujedno i čednom, ugladjenom, umjerenom i u cielom vanjskom vladanju milom i ljubežljivom." ${ }^{6}$ lako je pritom ponajprije mislio na škole, s obzirom na karakter Akademije kao znanstvene institucije, nesumnjivo je Strossmayer smatrao kako ce i njezina zgrada svojim arhitektonskim rješenjem utjecati na mlade i opcenito na građanstvo Hrvatske, što je jasno i istaknuo u pismu iz travnja 1875. tadašnjemu hrvatskom banu Ivanu Mažuranicu, vezanome za izgradnju palače Akademije, kojim ga je nastojao istodobno sklonuti „da sve što se u nas troši, gradi i za crkve i kuce nabavlja, ne bude bačen zahman novac, nego da bude zaisto ukusno i liepo". ${ }^{7}$

Ne samo zgrada Akademije vec i svi arhitektonski pothvati koje je Strossmayer financirao, vodio ili poticao 1860 -ih i 1870-ih - izgradnja i opremanje đakovačke katedrale, restauriranje crkve svetog Marka i katedrale u Zagrebu - sve riječi kojima je korio ili hvalio nova djela arhitekture po hrvatskim (pa i drugim europskim) gradovima bile su vođene istom mišlju. Stoga je i opširan opis svoje tada tek napola dovršene katedrale iz 1874. završio riječima: „Umotvorine bjehu za sve zemlje i narode prava učilišta, iz kojih se kratkim i uspješnim putem širila prosvjeta i ugladjenost. Narod bez umotvorina jest ujedno bez uzora za svoj viši duševni život." ${ }^{8}$

5 StROSSMAYER, 1874.a: 5

6 StROSSMAYER, 1875.g: 210

7 HR-HDA-78, PRZV, kut. 68, dosje VI-1023, 1875., Strossmayer Mažuranić, Đakovo, 17.4.1875.

8 Strossmayer, 1874.f: 144

9 ANDERSON, 2015: 24

10 HR-AHAZU, XI A/Krš. I. 16, Kršnjavi Strossmayeru, Rim, 19.4.1876.

11 Kako, uostalom, svjedoče riječi Franje Račkoga upucene Strossmayeru: „U ostalom mi necemo ništa učiniti prije, negoli Vaše mnijenje saslušamo, osobito glede sloga zgrade itd." [Šıšıć, 1928: 344-345, Raćki Strossmayeru, Zagreb, 2.4.1875.]

12 STROSSMAYER, 1874.e: 118

13 Šıšıć, 1928: 346, Strossmayer Račkomu, Đakovo, 6.4.1875.

14 Strossmayer, 1874.a: 5

15 Strossmayer, 1874.e: 118
Dakako, uvjerenje da se može 'podići ukus' u širim krugovima stanovništva novim kvalitetnim građevinama ili djelima umjetnosti i umjetničkog obrta u to je doba bilo iznimno rašireno u cijeloj (srednjoj) Europi. ${ }^{9}$ Njega ce prihvatiti i drugi istaknuti predstavnici onodobne intelektualne scene u Hrvatskoj. Vrlo slične opaske vezane za ulogu koju bi zgrada Akademije trebala imati u Zagrebu može se tako naci u dopisima Ise Kršnjavoga. „Galerija slika namienjena je pobuditi ukus i poznanje ljepote..." ${ }^{10}$ Koliko je Strossmayer svojim tekstovima utjecao na Kršnjavoga, a koliko možda Kršnjavi na njega, teško je reći, a još teže je ustanoviti koliko su odjeknule biskupove riječi u široj publici. Sigurno je, međutim, da ih se slušalo u krugu ljudi koji su vodili gradnju Akademije. Biskupu je, naime, zahvaljujuci velikoj darovnici od 40.000 forinti za izgradnju ove palače, pripadao svojevrstan veto na donošenje odluke o odabiru arhitekta, stilu, te u cjelini arhitektonskom rješenju zgrade, iako je formalno Franjo Rački, kao predsjednik Akademije, vodio poslove oko priprema za njezinu izgradnju. ${ }^{11}$

\section{„SAMO STVAR MORA BITI U SLOGU RENESANSE" - BISKUP STROSSMAYER I ARHITEKTONSKO RJEŠENJE PALAČE AKADEMIJE U ZAGREBU}

\section{"The PROJeCt NEEDS TO BE \\ IN RENAISSANCE STYLE" - BISHOP STROSSMAYER AND THE CONCEPTUAL DESIGN FOR THE ACADEMY PALACE IN ZAGREB}

Prvo i glavno što je Strossmayer uvjetovao vezano za novu palaču Akademije bio je odabir stila. Za sve je svoje graditeljske i umjetničke pothvate biskup bio, kako je dobro poznato, vođen idejom o nužnosti oslanjanja na povijesne predloške: „što se pako umjetnosti i djela njezinih tiče, ona posve tradicijom živi”. ${ }^{12} \mathrm{~A}$ koji je najprimjereniji povijesni predložak za palaču Akademije definirao je u samim početcima stvaranja ideje o njezinoj izgradnji, početkom travnja 1875., kada je jasno istaknuo Račkome vezano za izradu projekta: „Samo stvar mora biti u slogu renesanse.”13 | doista, svi projekti koje je Friedrich Schmidt izradio za palaču bili su u neorenesansnom stilu.

Pojam renesanse Strossmayer je poimao kao svojevrsnu posljednju etapu srednjega vijeka. Kao crkveni prelat smatrao je, naime, kako su najkvalitetnija umjetnička djela nastala u razdoblju od 10 . do 15 . stoljeća te da se već u 16. stoljeću počela umjetnost kvariti jer je svoj utjecaj na nju izgubilo svecenstvo. ${ }^{14}$ Što je od arhitektonskih djela 15. i 16. stoljeca, prije nego što je „umjetnost prava propadati počela" ${ }^{15}$ ulazilo u njegov kanon, jasno 
svjedoče riječi koje je uputio prisutnima pri otvaranju Galerije slika u palači Akademije 1884. godine. „Ja opetujem, da se duboko klanjam i današnjemu vremenu, ja se divim Schinkelovom muzeju u Berlinu i operi Semperovoj u Draždjanima; ja se divim universitetu i muzeju Ferstelovu pa akademiji i parlamentu Hansenovu u Beču; napose pak divim se bečkom Rathausu, koji je možebiti najljepši i najveći spomenik 19. vijeka; a i ova zgrada, u kojoj se mi danas nalazimo, lijepa je zaisto i uzorita; ali iskreno mi je reci: kad ja sve te divne zgrade prispodobim sa sličnim zgradama srednjega vijeka: sa palazzo Foscari i palazzo principa Giovanellija u Mlecima, sa palazzo Ducale u Urbinu, sa palazzo Vecchio, palazzo Pitti, palazzo Strozzi, palazzo Ricasoli i sa divnom galerijom Orcagne u Florenciji, sa palazzo Massimi, palazzo Farnese, villom Farnesinom i kancelarijom Raffaelovom u Rimu, onda ja prednost dajem spomenicima srednjega vijeka. A kada me se pita: zašto? - odgovaram evo zašto: stari su znali žar srca i duše svoje, koje je religiozno cuvstvo razgrijalo, prenijeti ne samo na religiozne, nego i na civilne spomenike, koje su gradili. Pak kada zdravo oko te zgrade sa sličnim zgradama našega vijeka prispodobi, odmah ce opaziti, da je više srca, više poezije, više rječitosti i uzoritosti u starim zgradama no u novijima." ${ }^{16}$ Ostvarenja renesansne arhitekture koje je smatrao djelima svećenika, ujedno je cijenio kao najvrsnija djela toga stila - palaču Farnese u Rimu te Strozzi i Ricasoli u Firenci. ${ }^{17}$

Strossmayer, dakako, renesansnu arhitekturu nije percipirao na potpuno jednak način kako je percipiramo danas. Definirao ju je kako bi je i danas većina povjesničara arhitekture definirala: „Renaisanca je u svojih težnjah i proizvodih nastojala, manjom ili vecom vještinom, manjim ili većim uspjehom, stare rimske sgrade uskrisiti i ponoviti."18 Djela koja su po njemu slijedila taj princip smatrao je stoga ostvarenjima renesansnog stila, bez obzira na to kada su nastala. lako je osuđivao 'grdni barokizam', pojedine građevine koje danas smatramo primjerima toga stila, oduševljavale su ga jer ih je smatrao kvalitetnim primjerima (kasne) renesanse. Za prašku palaču Clam-Galllas, glasovito djelo Johanna Bernharda Fischera von Erlacha s početka 18. stoljeća, isticao je tako da je „u najčistijem slogu renaissance sazidana”, a za palaču Czernin, podignutu u istome gradu u drugoj polovici 17. stoljeca, da je „u fiorentinskoj renaisanci od sama kamena zidana, tako liepa da bi jedva ljepšu u Fiorenci našao". ${ }^{19}$

Znao je katkad kritizirati druge autore koji renesansu nisu poimali kao on. U tekstu kojim je 1874. nastojao potaknuti restauriranje zagrebačke katedrale, spočitnuo je tako Karlu Weissu što je u poznatoj monografiji o ovoj građevini istaknuo da su oltari u bočnim apsidama (Blažene Djevice Marije i svetoga Ladislava), izrađeni krajem 17. stoljeca, nazvani renesansnim: „Da slavni Brunelleschi, graditelj divne florentinske kupole, izvedene po primjeru rimskoga pantheona, ustane i slučajno u Zagreb dospije, čudom bi se čudio, što se u Zagrebu renaissancom naziva." S druge strane, smatrao je da je jedna jedina zgrada u Zagrebu „koja nosi na sebi tragove liepe i umne renaisance", prizemlje i prvi kat nekadašnjega isusovačkog samostana, za koje je mislio, procjenjujuci ih na osnovi arhitektonske dekoracije, da su podignuti u 15 . ili početkom 16. stoljeća, što dakako nije točno. Samo mu je drugi kat na toj zgradi „dodatak jezovanski, nevriedi ništa”. Budući da je donje dijelove samostana smatrao ostvarenjima renesanse, preporučivao je stoga suvremenicima da „tko misli lijepu sgradu u Zagrebu sazidati, neka po tom primjeru zida". ${ }^{20}$

lako je renesansu Strossmayer poimao kao posljednju etapu 'srednjeg vijeka', nesumnjivo je da je jasno razlikovao ostale stilove ovoga razdoblja, romaniku i gotiku, od renesanse. Dok je romaniku i gotiku smatrao prikladnima ponajprije za crkve, renesansu je počeo preferirati u profanoj, osobito javnoj arhitekturi. Pritom je u najpoželjnije uzore za suvremene građevine ubrajao najvažnija djela toga stila, podignuta u Firenci u 15. i Rimu početkom 16. stoljeća.

Kako ce se vidjeti, Schmidtovi projekti za Akademiju oslanjaju se u većoj mjeri na rimsku renesansu ranoga 16 . stoljeca, dok je firentinska renesansa poslužila kao svojevrstan ideološki uzor. Umjetnička baština ovoga grada osobito je, naime, nadahnjivala Strossmayera pa je stoga Zagreb htio učiniti Firencom Hrvatske, a Hrvatsku Toskanom južnoga slavenstva, odnosno, kako je to poetično istaknuo, nastojao je „da se u Zagrebu obce ognjište stvori, na komu bi se sav jug razgrijao". ${ }^{21}$ Dakako, upravo je Akademija, kao institucija koja je trebala služiti za potporu znanosti i umjetnosti, imala, kako je i istaknuo pri otvorenju Galerije, posebnu ulogu: „da domovini našoj na Balkanskom poluotoku osobito opredieljene pripišemo, to jest da postane to, što Toskana u lijepoj Italiji, da postane osobite vrsti Athenaeum, što ce reci ognjište i njegovalište svih umnih i moralnih

\footnotetext{
16 SMIČIKLAS, 1906: 198. Govor pri otvorenju Galerije slika 9. studenoga 1884 .

17 StrosSMAYER, 1877.a: 1

18 StrosSMAYER, 1874.g: 7

19 StrossmaYeR, 1875.C: 53

20 STROSSMAYER, 1874.g: 7

21 StrossmaYer, 1877.b: 1

22 SMIČIKLAS, 1906: 183. Govor pri otvorenju Galerije slika 9. studenoga 1884 .

23 SMIČIKLAS, 1906: 184. Govor pri otvorenju Galerije slika 9. studenoga 1884 .
} 
težnja i svrha”. ${ }^{22} \mathrm{Na}$ ovu se misao nadovezuje i sljedeca: „Ako se takve zgrade, ko što je ova, u stolnom gradu našem širile budu, grad ce naš ubrzo ne samo nutarnjim bicem i opredjeljenjem svojim, nego $\mathrm{i}$ vanjskim licem i obličjem slavni i neumrli naš Dubrovnik zamijeniti, ili, kad sam već prije hrvatsku našu domovinu na Balkanskom poluotoku prispodobio Toskani, to ce zgrade ovoj našoj akademičkoj zgradi slične, kada se uzmnože, pretvoriti stolni naš grad, ako Bog da, makar i u čednoj mjeri, u lijepu i uzoritu Florencu."23

Osim što je odraz Strossmayerova odnosa prema javnoj arhitekturi, fascinacije umjetnošcu 15. i 16. stoljeća u Italiji, te želje da se Zagreb pretvori u novu Firencu - odabir upravo talijanske renesanse kao stila palače Akademije proistekao je uvelike i iz okolnosti da je ova zgrada od samih početaka zamišljena i kao sjedište Strossmayerove galerije, dakle kao muzejska zgrada koja je i svojim izgledom i odabirom stila trebala svjedočiti o ovoj funkciji.

Putujuci Europom 1860-ih i 1870-ih Strossmayer je, naime, imao prilike posjetiti ključne novije i starije zbirke slika i muzeje. Opisao ih je u svojim člancima ili pismima prijateljima i rodbini, i to kako ono što ga je od umjetnina fasciniralo, tako i zgrade koje su udomljivale ove zbirke. Upravo se iz tih njegovih tekstova jasno mogu rekonstruirati koraci u razvijanju ideje o arhitektonskom i stilskom rješenju palače Akademije u Zagrebu.

Na prvome se mjestu iz tekstova može iščitati da je biskup korištenje klasicizma grčkih korijena smatrao neprihvatljivim u suvremenoj arhitekturi. Smatrao je da su grčke građevine bile namijenjene manjim mjestima i ne valjaju ako se prenesu u vece mjerilo: „One su bile uzor za grčki život, za grčko podnebje, za male grčke gradove. Njihova architektura vrlo je nježna, divno urešena i zaisto uzorna, ali se je obično kretala u manjemu razmjerju. Takvih liepih grčkih sgrada viditi je u južnoj Italiji, na pose pako u Pompeju skoro u svoj svojoj cielosti. Ali prenesi te sgrade iz južne Italije ili iz same Grčke u Beč, u Berlin, u Petrograd, pak ceš odmah opaziti, da jim tuj nije mjesta, i da tuj svu svoju prvobitnu ljepotu gube. Svaki architekt mora paziti, gdje gradi." ${ }^{24}$ Stoga mu se nije svidjela ni arhitektura muzeja sagrađenog $\mathrm{u}$ tom stilu, Schinkelova

\footnotetext{
24 Strossmayer, 1875.e: 85

25 STROSSMAYER, 1875.f: 89

26 Strossmayer, 1875.f: 90

27 StROSSMAYER, 1875.d: 76

28 Strossmayer, 1875.g: 115-116

29 Strossmayer, 1875.a: 15

30 Osobna ostavština obitelji Lubienski, Graz, Strossmayer Albertini Unukic, Beć, 10.7.1879.

31 DAmJANOVIC, 2009.a: 132-140
}

Starog muzeja u Berlinu, vezano za kojeg je zaključio „da se od prevelikog grecizovanja u vecih varoših čuvati imamo". ${ }^{25}$

S druge strane, renesansu je smatrao potpuno prikladnim stilom u suvremenoj arhitekturi, a osobito u arhitekturi zgrada muzeja i galerija. Berlinski Novi muzej, koji stoji uza stariju spomenutu klasicističku Schinkelovu zgradu, stoga mu se svidio ,prekrasna [je] to sgrada u slogu renaissance”. ${ }^{26}$ Još ga je više na istome putovanju Njemačkom 1874. godine, koje je godinu poslije detaljno opisao, fascinirala Semperova zgrada drezdenske Galerije slika: „Sudi se u obce, da je to najljepša i najizvrstnija sgrada novijega vremena, u slogu klasičke renaissance. Ja mislim da ce svaki, koji tu sgradu vidi rado priznati, da je sgrada pravi remek...."27

$\mathrm{Na}$ istome je putovanju od svih muzejskih zgrada u Münchenu isto tako najboljom smatrao neorenesansnu Klenzeovu Pinakoteku: „Sgrada je to vrlo liepa, u slogu renaissance ... sazidana”, ${ }^{28}$ a u Beču Ferstelov Austrijski muzej za umjetnost i industriju (danas Muzej primijenjenih umjetnosti). „Što se novih sgrada tiče, mnogo jih ima dakako lijepih i ukusnih. Medju najljepše spada austrijski muzej..."29 Ferstelova zgrada, oslonjena na ranu firentinsku renesansu, pročelja izvedenih od fasadne opeke i prekrivenih djelomično s graffitom, potpuno se uklapala u biskupove estetske nazore pa ne cudi što je i rješenje zagrebačke palače Akademije na tome tragu.

Nekoliko godina nakon tog putovanja, kada je u srpnju 1879. boravio u Beču i prvi puta vidio tada tek djelomično dovršene nove zgrade carskih muzeja Gottfrieda Sempera i Carla von Hasenauera (koje je, kako ce se vidjeti iz citata, također smatrao vrsnim primjerima (neo)renesansne arhitekture), zadivljeno je na tome tragu pisao svojoj necakinji Albertini Unukic. „Nemojte propustiti pogledati pred 'burgom' dva museja od Sempera. Po momu osviedočenju naliepše sgrade u renaisancu, u cieloj Europi, u devetnaistom stolecu. Nemogu reć, koliko mi se te dvie sgrade dopadaju!"30

Konačno stilsko rješenje palače Akademije nije, međutim, biskup definirao sam - ono je rezultat svojevrsne sinergije Strossmayerovih želja i ideja arhitekta koji je projektirao palaču - Friedricha Schmidta (kao što je, uostalom, bio slučaj i s definiranjem stilskog rješenja katedrale u Dakovu). ${ }^{31}$ Kako se kod toga arhitekta uobličila ideja o stilskom rješenju palače, svjedoči pismo koje je uputio Strossmayeru iz Beča sredinom travnja 1875., vezano za izradu prvoga projekta za zgradu Akademije, koje predstavlja u širim razmjerima zanimljivo svjedočanstvo vezano za proces odabira stila u arhitekturi historicizma. Schmidt je, naime, istaknuo biskupu da se 
pitanje stila nove palače treba uskladiti s fiziognomijom grada Zagreba i 'umjetničkim sadržajem zbirke' koja ce biti udomljena u zgradi.

Pod prvim je nesumnjivo podrazumijevao opcenite odlike arhitekture Zagreba i klimu prostora u kojem se grad nalazi. I one su ga, kao i okolnost da je najveći dio djela koja je u svojoj galeriji skupio Strossmayer (a koja je Schmidt imao prilike dobro upoznati dok je boravio kod njega na dvoru u Đakovu radeći na izgradnji i opremanju đakovačke katedrale), dovele do zaključka kako ni antika (odnosno klasicizam) ni srednji vijek (odnosno romanika ili gotika) nisu pogodni kao stil zgrade, vec samo renesansa. Schmidt je, međutim, objasnio kako je i renesansa iznimno složen stilski fenomen, jer ne samo da postoji talijanska, njemačka ili francuska renesansa vec i brojne druge 'nijanse'. Zaključak do kojeg je naposljetku došao, osobito s obzirom na karakter Strossmayerove umjetničke zbirke u kojoj su prevladavala djela talijanskih majstora, jest da je najprikladniji stil rana talijanska renesansa. ${ }^{32}$

Strossmayerov i Schmidtov odabir upravo talijanske renesanse kao stila najprikladnijega za palaču Akademije u potpunosti se nadovezuje na dominantne tendencije u javnoj i stambenoj arhitekturi Europe 1870 -ih godina. Prve realizacije neorenesanse nalazimo vec od 1820-ih u djelima Lea von Klenzea, pa potom nešto kasnije Gottfrieda Sempera, Félixa Dubana i drugih arhitekata, no tek ce se tijekom 1850 -ih ovaj stil u vecoj mjeri proširiti čitavom europskom arhitekturom. Zahvaljujuci (između ostaloga) kultnim knjigama Jacoba Burckhardta Kultura renesanse $u$ Italiji (1860.) ${ }^{33}$ i Povijest renesanse $u$ Italiji (1868.) ${ }^{34}$, talijanska neorenesansa postaje od 1860 -ih godina nadalje dominantan stil javne i stambene arhitekture $u$ kontinentalnoj Europi.

lako se paralelno javljaju arhitektonska ostvarenja i u drugim regionalnim ('nacionalnim') varijantama neorenesanse (francuskoj, njemačkoj, češkoj, mađarskoj itd.), talijanska neorenesansa ostat ce tijekom cijele druge polovice 19. stoljeća najraširenija. Za razliku od ostalih, regionalnih odnosno nacionalnih varijanti, ona se smatrala svojevrsnim nadnacionalnim kozmopolitskim stilom, primjerenim za sve građevine modernih funkcija. Rudolf Eitelberger von Edelberg, prvi profesor povijesti umjetnosti na Bečkom sveučilištu, koji je tijekom 1873., prije no što ce Strossmayer naručiti projekte za zgradu Akademije, komunicirao s biskupom Strossmayerom i cije je tekstove Strossmayer dobro poznavao, naglašavao je tako univerzalnost i višu estetsku vrijednost talijanske renesanse, nasuprot francuskoj ili njemačkoj renesansi ${ }^{35}$, kao i okolnost da je taj stil nastao u Italiji te da su sve ostale nacionalne verzije renesanse samo izvedenice. ${ }^{36}$ Eitelbergerova stajališta utjecat ce na iznimnu raširenost talijanske renesanse $u$ arhitekturi historicizma Austro-Ugarske Monarhije ${ }^{37}$ i u njenoj prijestolnici Beču, gdje se pretvorila, kako je to isticao kritičar Ludwig Hevesi, u svojevrstan adoptirani nacionalni stil. ${ }^{38}$

Talijanska se renesansa smatrala svojevrsnim utjelovljenjem humanizma u umjetnosti39, odnosno, kako je to isticao Jackob Burckhardt, „majkom i domovinom modernog čovjeka".40 Za ovaj su se stil vezivala, dakle, potpuno druga, katkad čak i antiklerikalna značenja ${ }^{41}$, u odnosu na ona koja mu je pripisivao Strossmayer. No, bez obzira na to što su ideološka polazišta za renesansu renesanse kod Strossmayera bila drukčija negoli kod spomenutih njegovih srednjoeuropskih suvremenika, rezultati su bili isti - naglo širenje toga stila u onodobnoj arhitekturi.

\section{ODABIR ARHITEKTA}

\section{CHOICE OF THE ARCHITECT}

lako je svojim tekstovima iz 1870-ih poticao širenje neorenesanse, Strossmayer nije uvijek sa simpatijama gledao na prve primjere toga stila u Hrvatskoj. Takozvanu Varošku kuću, podignutu početkom 1870-ih u središtu osječkoga Gornjeg grada, ocijenio je tako pravim nonsensom. ${ }^{42}$ Buduci da se radi o kvalitetnom primjeru neorenesanse, očito je kako je biskupu zasmetalo što Osijek nije angažirao nekoga viđenijeg arhitekta na njezinu projektiranju. Strossmayer je, naime, inzistirao pri svojim graditeljskim pothvatima na povjeravanju poslova prvoklasnim, najčešce bečkim arhitektima. Stoga je smatrao kako bi Osijek daleko bolje (a możda i povoljnije) prošao da je projekt povjerio Heinrichu Ferstelu, Theophilu Hansenu, Carlu von Hasenaueru ili Gottfriedu Semperu, uz koje je spo-

\footnotetext{
32 HR-AHAZU, XI A/Schmi. 2, Schmidt Strossmayeru, Beć, 18.4.1875.

33 BURCKHARDT, 1860.

34 Rijeć je o monografiji koja se usredotočuje najvecim dijelom na povijest arhitekture renesanse. [BURCKHARDT, 1868.]

35 Eitelberger, 1879: 394

36 Eitelberger, 1879: 392

37 Mennekes, 2005: 26

38 „Adoptiv-Nationalstil”, ANDERSON, 2015: 29

39 WAGNER-RIEGER, 1970: 156

40 Bolzoni, PAYne, 2018: 9

41 Bolzoni, PAYNe, 2018: 13

42 Strossmayer, 1874.d: 77

43 STROSSMAYER, 1874.d: 78

44 Šıšıć, 1928: 344-345, Rački Strossmayeru, Zagreb, 2.4.1875.

45 HR-AHAZU, XI A/Krš. I. 4, Kršnjavi Strossmayeru, Rim, 12.5 .1875 .

46 NAD, CGO bb, Schmidt Strossmayeru, Beč, 5.6.1875.
} 
menuo kao poželjne i talijanske arhitekte Antonija Cipollu, Camila Boita, Andrea Scalu i Salvatorea Zerija. ${ }^{4}$

S obzirom na važnost koju je pridavao palači Akademije, razumljivo je da su kod Strossmayera pri odabiru arhitekta i za izradu njezina projekta u obzir dolazili samo najbolji arhitekti, na prvome mjestu bečki. Pritom je Friedrich Schmidt, kako je jasno iz prethodnoga dijela teksta, od samih začetaka ideje o gradnji nove palače Akademije važio kao glavni kandidat za njezina projektanta, no sve do početka gradnje zgrade 1877. pojavljivale su se i druge mogucnosti.

Kako je nastanak ideje o potrebi gradnje palače Akademije i galerije vezan za početak prijateljevanja biskupa Strossmayera s Isom Kršnjavim (na prijelazu iz 1874. u 1875. godinu), prvi hrvatski povjesničar umjetnosti odigrat ce važnu ulogu u odabiru arhitekta. Kršnjavi je, naime, iskoristio svoje prijateljstvo s biskupom Strossmayerom kako bi sugerirao što primjerenije rješenje za palaču HAZU, a poslije i kako bi požurivao njezinu izgradnju, jer je realizacija ove zgrade bila povezana $s$ njegovim zapošljavanjem i osnivanjem Katedre za povijest umjetnosti na Zagrebačkom sveučilištu. Znajući da Strossmayer inzistira na talijanskoj renesansi kao stilu, Kršnjavi je sugerirao biskupu kako bi bilo najbolje odabrati nekoga od specijalista za taj stil iz Beča - Ferstela, Hansena ili Sempera, jer se uplašio da se ne odabere, po savjetu kanonika Račkoga - Heinricha Schmidta, sina Friedricha Schmidta ${ }^{44}$, kao projektanta. Njega je, naime, smatrao neiskusnim za takav posao. „Nadam se još nječemu! A to je, da ce ostati onako kako se dogovorismo glede sgrade za galeriju, t.j. da ce Vaša preuzvišenost o tom predmetu viećati sa Hansenom ili Ferstelom u Beču. Vrlo sam se naime preplašio čitavši u Viencu i čuvši od Voršaka, da je Rački tu stvar povjerio mladomu Šmidtu. Ja mladoga

47 NAD, CGO, Schmidt Strossmayeru, Beć, 2.10.1875.

48 *** 1876: 256; DAMJANOVIĆ, 2009.b: 112

49 ŠıŠıĆ, 1929: 13, Rački Strossmayeru, Zagreb, 10.4 1876.; MARUŠEVSKI, 1986: 112

50 MAROEVIC, 1968: 64

51 DULIBIC, PASINI TRŽEC, 2018: 283-284

52 Tartaglia Kelemen, 1973: 198; Kršnjavi Mrazovicu, Rim, 21.3.1875.

53 „Ja idem mjesecom junijom u Beč. Ako dotle odlučeno bude mjesto, i ako se opredijele potanko prostorije, mogao bi onda ja sam sa Hansenom ili sa Försterom govoriti.” lako spominje Förstera, sigurno je da misli na Heinricha Ferstela, jer prezime tog arhitekta cesto krivo navodi. [Šıšıć, 1928: 344, Strossmayer Raćkomu, Đakovo, 31.3.1875.]

54 Šıšıć, 1928: 355, Strossmayer Račkomu, Đakovo, 26.5.1875.

55 lako je protiv njegova angažiranja bio Nikola Voršak, kanonik pri Svetom Jeronimu u Rimu, koji je biskupa nastojao nagovoriti da angażira nekoga od talijanskih arhitekata, svojih prijatelja. [Šıšıc, 1928: 353, Rački Strossmayeru, Zagreb, 21.5.1875.

56 Strossmayer, 1877.a: 2
Šmidta ne poznajem, a niti ga itko u Beču poznaje kao samostalnog arhitektu - uz otca, izvan gotičkog styla, nije mogao naučiti toliko, da bi sa Semperom, Hansenom ili Ferstelom u stylu Renaisenca takmiti se mogao.”45

Do angažiranja Henricha Schmidta ipak nece doci. Čini se, doduše, ne zbog savjeta Kršnjavoga, već stoga što je ovaj arhitekt najprije u svibnju 1875 . bio pozvan kao rezervni casnik da služi u utvrdi Theresienstadt ${ }^{46}$, da bi potom $u$ jesen 1875. bio angažiran na restauraciji katedrale u Frankfurtu pa se odselio iz Beča, a Schmidt je na projektima za Zagreb, zgrade Akademije i crkve Svetoga Marka, angažirao kao pomocnika svojeg učenika Enrica Nordija. 47 Ubrzo ce Nordija, kako je dobro poznato, zamijeniti Herman Bollé, kojega ce Schmidt poslati krajem 1875. u Italiju da prouči kako su građeni tamošnji muzeji i galerije, vezano za izradu projekta palače Akademije u Zagrebu, ali i da prouči detalje renesansnoga stila. ${ }^{8}$ Stjecajem okolnosti Bollé se susreo u Rimu, vjerojatno u prvim danima 1876., s Kršnjavim i Strossmayerom, što ce njegov životni put sudbinski usmjeriti prema Hrvatskoj.

Osim Schmidta, projekte za palaču Akademije izradio je u travnju 1876. i glasoviti Hermann Helmer, koji ce se poslije s Ferdinandom Fellnerom promaknuti u ključnoga arhitekta kazališta u Europi ${ }^{49}$, a zatim, početkom 1877., zagrebački arhitekt Janko Josip Grahor ${ }^{50} \mathrm{i}$ arhitekt amater August Posilovic ${ }^{51}$, no ovi se projekti, za sada, nisu mogli pronaci. Konačno, još početkom 1875 . jedan je projekt izradio i sam Kršnjavi ${ }^{52}$, ali o njegovoj se realizaciji, čini se, nikada nije razmišljalo.

U to je doba, vjerojatno zbog savjeta Kršnjavoga, Strossmayer namjeravao na projektiranju palače angažirati Theophila Hansena ili Heinricha Ferstela ${ }^{53}$, i to stoga što su, kako je istaknuo u pismu Račkom: „Ova dvojica [...] u renesansi vještija od Schmidta." 54 Usto, radilo se o arhitektima koji su imali iskustva s projektiranjem građevina muzejske namjene.

Usprkos svim preporukama i premda su Hansen, Ferstel i Semper bili doista daleko specijaliziraniji za rad u neorenesansnom stilu, na kraju je izbor ipak pao na Schmidta. ${ }^{55}$ Čini se, ponajprije zahvaljujuci okolnosti da se s tim arhitektom biskup dobro poznavao, ali i stoga što ga je iznimno cijenio. Tom je odlukom naposljetku bio više nego zadovoljan. Smatrao je da ce arhitektu Schmidtu „na vječitu slavu služiti, što je prvi u naših stranah boljemu ukusu put prokrčio". ${ }^{56}$

Od naručivanja projekta od Schmidta do početka izgradnje građevine proći ce, međutim, znatno više vremena nego što je biskup očekivao, i to zbog promjena lokacije i namjene građevine, što ce uvjetovati nastanak čak triju različitih projekata za palaču. 


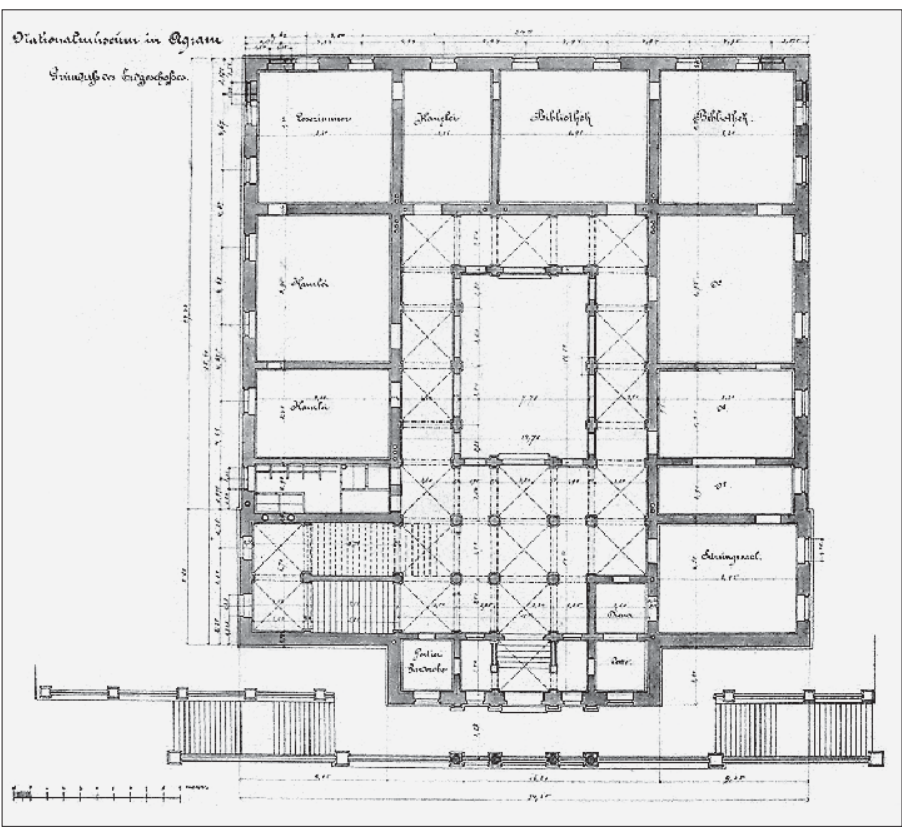

SL. 2. F. SCHMidt: TLOCRT PRIZEmLja AKAdemije I GALERIJE SLIKA U ZAGREBU, 1875.

FIG. 2 F. SCHMIDT: ACADEMY AND THE GALLERY

OF PAINTINGS IN ZAGREB, GROUND-FLOOR PLAN, 1875

SL. 3. F. SCHMidt: TLOCRT PRVOga Kata AKademiJe I GALERIJE SLIKA U ZAGREBU, 1875.

FIG. 3 F. SCHMIDT: ACADEMY AND THE GALLERY OF PAINTINGS IN ZAGREB, FIRST-FLOOR PLAN, 1875

\section{PRVI PROJEKT ZA PALAČU AKADEMIJE I GALERIJU SLIKA, 1875.}

\section{FIRST PROJECT FOR THE ACADEMY PALACE AND THE GALLERY OF PAINTINGS, 1875}

Početkom 1875., upravo u doba kad je najintenzivnije pisao i objavljivao tekstove o obnovi hrvatske umjetnosti, kad je udario temelje restauraciji crkve svetoga Marka i katedrale u Zagrebu, biskup Strossmayer odlučio je istodobno započeti s realizacijom projekta sjedišta Akademije. Čini se da je ključnu ulogu u toj odluci odigrao spomenuti početak prijateljevanja s Isom Kršnjavim u Rimu na prijelazu 1874. na 1875 . godinu ${ }^{57}$, odnosno nastojanje da ga se imenuje profesorom povijesti umjetnosti na Zagrebačkom sveučilištu. Smatrao je da nova katedra na Sveučilištu mora nužno biti vezana za njegovu galeriju slika ${ }^{58}$, za koju se planiralo isprva da bude smještena u dogradnji Narodnoga doma u Opatičkoj 18, da bi se ubrzo potom, čini se već u veljači ili ožujku 1875., iskristalizirala ideja o potrebi izgradnje potpuno nove zgrade u kojoj bi bila smještena zajedno s uredima Akademije. Darovao je stoga JAZU-u 26. ožujka 1875. za ono doba golem iznos od 40.000 forinti za podizanje nove zgrade. ${ }^{59}$ Kršnjavi je uvidio da njegova karijera u Hrvatskoj u potpunosti ovisi o tom projektu pa je sve do početka gradnje zgrade budno strepio nad svakim korakom u njegovoj realizaciji.

Svjestan da darovana svota, koliko god da je velika, nije dovoljna za izgradnju monumentalne palače, Strossmayer se odmah po povratku iz Rima u Hrvatsku u ožujku 1875., za- jedno s Račkim, upustio u intenzivno lobiranje kod tadašnje hrvatske vlade $\mathrm{s}$ banom Ivanom Mažuranićem na čelu i kod vlasti grada Zagreba s gradonačelnikom Ivanom Vončinom da pripomognu gradnju palače dodjelom novčane potpore i zemljišta. ${ }^{60}$ Obje su razine vlasti načelno poduprle inicijativu, a odbor Gradskog zastupstva gotovo je odmah donio odluku, što je dobro poznato, o darovanju zemljišta za njezinu izgradnju na zapadnomu kraju Strossmayerove promenade, na platou Griča, uz palaču tadašnje Realne gimnazije. ${ }^{61}$

Da bi se osigurala daljnja potpora vlasti, trebalo je, međutim, imati završene projekte i troškovnik pa ih je Rački od travnja do srpnja 1875. posredovanjem Strossmayera stalno nastojao ishoditi od Schmidta, koji je, kako je spomenuto, u konačnici odabran kao arhitekt.

Koliko se dade zaključiti iz sačuvane korespondencije, Schmidt je počeo raditi na skicama za prvi projekt Akademije vjerojatno početkom svibnja $1875 .{ }^{62}$ Buduci da je predviđao previše veličanstvenu zgradu, već početkom srpnja, na sugestiju Kršnjavoga, a i zbog nedostatka sredstava, prvi je put bio prisiljen pristupiti modifikaciji rješenja. ${ }^{63} \mathrm{Ta}$ prvotna skica, na žalost, nije sačuvana, pa

57 DAMJANOVIC, 2008: 198

58 ŠIŠIĆ, 1928: 333, Strossmayer Raćkomu, Rim, 6.1.1875. $59{ }^{* * *}$ 1875.a: 1; *** 1875.b: 72; HORVAT, 1925: 216-217; DULIBIC, PASINI TRŻEC, 2018: 272-273

60 ŠıŠıC, 1928: 342-343, Strossmayer Račkomu, Đakovo, 26.3.1875.

61 Strossmayer je o tome odmah obavijestio Kršnjavoga. [HR-HDA-804, KI, kut. 4, III/3, Strossmayer Kršnjavom, Đakovo (?), 29.3.1875.; KNEŻEVIĆ, 1996: 54] 


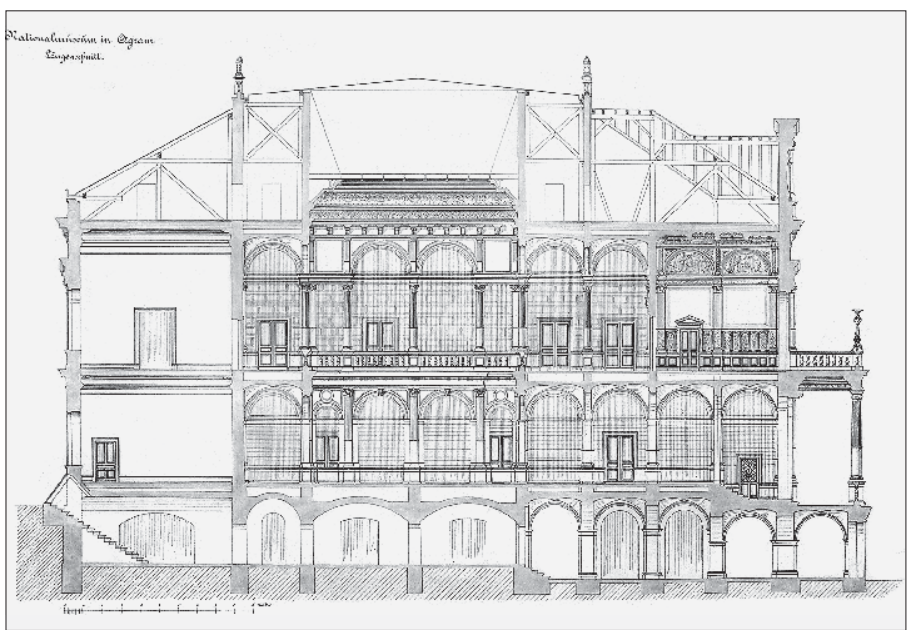

nije poznato koliko se razlikuje od prvoga projekta za palaču. Čini se da je bila vrlo brzo gotova i nova skica ili preliminarni projekt, koji su potom sredinom srpnja 1875. donijeli osobno Strossmayer i Kršnjavi iz Beča u Zagreb. ${ }^{64}$ Krajem istoga mjeseca biskup ga je donio na uvid tijelima Gradskoga poglavarstva, s kojima je u to doba raspravljao o (Schmidtovim) projektima za restauriranje crkve svetoga Marka. ${ }^{65}$ Projekt za Akademiju Schmidt je u cijelosti završio tek u listopadu iste godine ${ }^{66}$, ali ni tada nije bila donesena konačna odluka o njegovoj realizaciji.

Listovi prvoga projekta za palaču Akademije iz 1875. sačuvani su u ostavštini Friedricha Schmidta u Muzeju grada Beča, dok se jedna skica čuva i u Nadbiskupskom arhivu u Zagrebu. ${ }^{67}$ Osim glavnoga pročelja i situacije (koji su objavljeni još u „Viencu” 1876.), sačuvane su još dvije verzije nacrta bočnoga pročelja te tlocrti i presjeci (SI. 2.-10.).

Projektom iz 1875. bila je predviđena gradnja jednokatne zgrade na visokim supstrukcijama u kojima bi se nalazio podrum, a koje bi se protezale ispod čitave palače. lako funkcija podruma nije naznačena, može se pretpostaviti da bi služio kao skladište, a i trebao je izdići građevinu kako bi se ona bolje mogla vidjeti na platou. Prvi bi kat, po projektu, bio namijenjen uredima i knjižnici Akademije, dok bi se na drugome katu nalazila Galerija slika te prostrana i reprezentativno raščlanjena prostorija namijenjena sjednicama Akademije. (Sl. 2.-3.)

62 NAD, CGO, Schmidt Strossmayeru, Beć, 2.5.1875.

63 HR-AHAZU, XII A 332/4, Kršnjavi Račkom, 2.7.1875.

64 ŠıŠıć, 1928: 366, Strossmayer Račkom, Weidling, 18.7.1875.; KNEŻEVIC, 1996: 54

$65 * * * 1875 . \mathrm{C}: 3$

66 NAD, CGO, Schmidt Strossmayeru, 2.10.1875.

67 HR-NAZ, DM, ZGN, sign III-33
Sačuvani presjeci svjedoče kako bi u unutrašnjosti zgrada imala dvokatni, staklom natkriven atrij koji bi bio okružen arkadama, u prizemlju oslonjenima na stubove, a na katu na stupove. Središnji i reprezentativni prostori palače (poput dvorane za sjednice) bili bi bogato dekorirani (SI. 4.-5.).

Projekt iz 1875. predviđao je vrlo zanimljivo rješenje pročelja. Supstrukcije bi bile raščlanjene nekom vrstom grube rustike, a prizemlje manje naglašenom rustikom. Pretpostavlja se da bi pročelja obaju katova bila izvedena od kamena, dok bi pročelje prvoga kata bilo prekriveno, sudeći po načinu na koji ga je prikazao Schmidt na projektu, fasadnom opekom. Prozori u središnjem, rizalitno istaknutom dijelu pročelja bili bi bogato uokvireni, dok bi se na bočnim stranama nalazile niše sličnih arhitektonskih odlika sa skulpturama. Ikonografski program skulptura nije, na žalost, naznačen niti u jednomu sačuvanome pismu Strossmayera ili Schmidta iz 1875. Konačno, u zoni krovišta palaču je trebao kruniti maleni zabat s grbom Trojedne Kraljevine Hrvatske, Slavonije i Dalmacije. Osim za stupove trijema Schmidt je na preostalim dijelovima pročelja i u unutrašnjosti koristio korintski red pri oblikovanju stupova i pilastara (SI. 6.).

Schmidt je izradio najmanje tri varijante prvoga projekta, no koliko su se u cjelini one razlikovale, zapravo se ne može pouzdano ustanoviti jer nisu sačuvani svi listovi projekta za sve tri varijante. U Muzeju grada Beča čuvaju se tako dvije varijante za bočno pročelje. Kolorirana i datirana varijanta, na kojoj stoji i Schmidtov potpis, predvidjela je uokvirivanje prozora na prvome katu polustupovima, dok je nekolorirana, nedatirana i nepotpisana predlagala jednostavnije rješenje prozora, uokvirenih plitkom arhitektonskom plastikom. Varijante se međusobno razlikuju i u rješenju krovišta (SI. 7.-8.).
SL. 4. F. SCHMIDT: UZDUŽNI PRESJEK ZGRADE AKADEMIJE I GALERIJE SLIKA U ZAGREBU, 1875.

FIG. 4 F. SCHMIDT: ACADEMY BUILDING AND THE GALLERY OF PAINTINGS IN ZAGREB, LONGITUDINAL SECTION, 1875

SL. 5. F. SChmidt: PopreČnI PRESJek Zgrade AKademije I GALERIJE SLIKA U ZAGREBU, 1875.

FIG. 5 F. SCHMIDT: ACADEMY BUILDING AND THE GALLERY of Paintings in Zagreb, CROSS-SECTION, 1875 


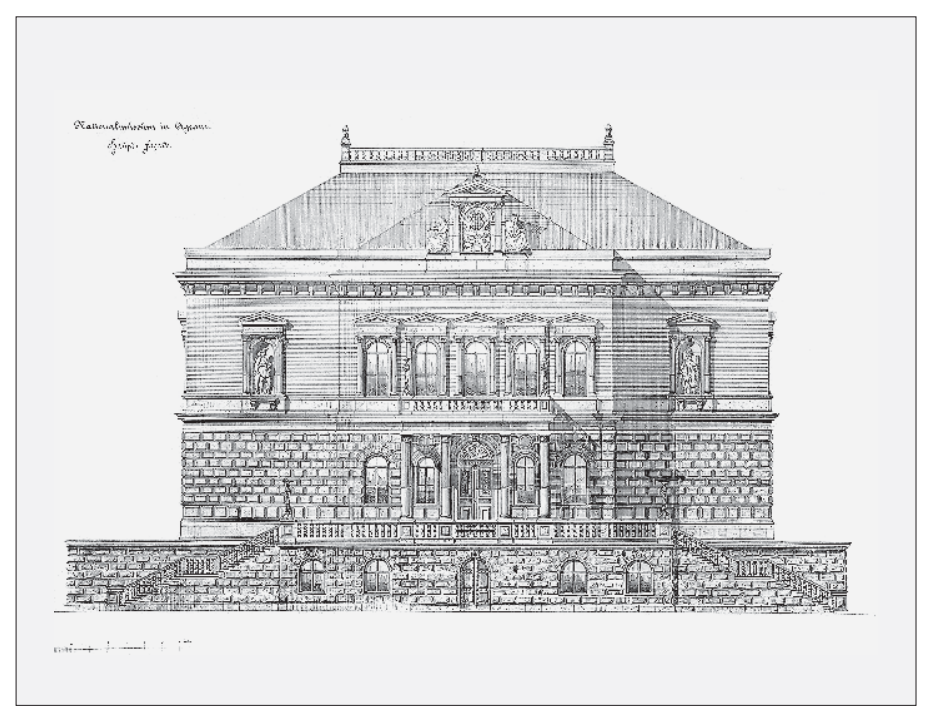

SL. 6. F. SCHMidT: Projekt ZA GLAVNo PRoČElJE AKADEMIJE I GALERIJE SLIKA U ZAGREBu, 1875. FIG. 6 F. SCHMIDT: ACADEMY AND THE GALLERY OF PAINTINGS IN ZAGREB, MAIN FACADE, 1875

SL. 7. F. Schmidt: Projekt za boćno proćelje AKademije I GALERIJE SLIKA U ZAGREBU, KOLORIRANA I POTPISANA VARIJANTA, 1875.

FIG. 7 F. SCHMIDT: ACADEMY AND THE GALLERY OF PAINTINGS IN ZAGREB, SIDE FACADE, COLOURED AND SIGNED VERSION, 1875
U Nadbiskupskom arhivu u Zagrebu čuva se pak jedan tlocrt palače Akademije koji se, sudeći po smještaju stubišta, također može vezati za varijante prvoga projekta iz 1875., a koji je predviđao postavljanje kružnoga erkera na ugao zgrade sa strane začelja.

U Schmidtovoj ostavštini u Muzeju grada Beča među projektima koji se odnose na palaču Akademije u Zagrebu nalazi se jedan list na kojem je olovkom skicirana zgrada koja bi mogla predstavljati upravo rješenje palače Akademije s erkerom na stražnjoj strani. Buduci da projekt nije jasno signiran ni datiran, ne može se isključiti niti mogucnost da je zabunom umetnut u dosje koji se odnosi na zagrebačku Akademiju. Ako se odnosi na Zagreb, po svoj je prilici nastao nakon Schmidtova razgovora s predstavnicima zagrebačkoga Gradskog poglavarstva u jesen 1875., kada je taj arhitekt najavio stanovite promjene projekta za Akademiju, tada još uvijek predviđenu za lokaciju na Griču. ${ }^{68}$ Taj je projekt predviđao građevinu približno sličnog volumena, ali drukčijega rješenja pročelja, koje bi u prizemlju bilo otvoreno s vecim brojem prozorskih otvora; kat bi imao nešto jednostavnije raščlanjene bočne dijelove pročelja, bez niša sa skulpturama, dok bi erker bio iznimno bogato dekoriran i pokriven kupolom. Ta se skica u odnosu na preostale varijante prvoga projekta za Akademiju razlikuje donekle i u stilu. Na njoj se, naime, Schmidt u vecoj mjeri oslonio na njemačku, a ne talijansku renesansu koja je bila osnovno polazište pri izradi (svih) ostalih projekata za palaču Akademije (Sl. 9.).

Do realizacije projekta iz 1875 . nece doci, kako je vec dobro poznato, zbog protivljenja ideji da se palača podigne na platou Griča. Ova su se protivljenja počela javljati već na sjednici na kojoj je, u travnju 1875., zagrebač- ko Gradsko zastupstvo formalno odobrilo darovnicu za zemljište na toj lokaciji. ${ }^{69}$ I Strossmayer i Schmidt i Rački i Kršnjavi smatrali su tu lokaciju iznimno poželjnom ${ }^{70}$ jer bi Akademija postala jedna od najdominantnijih zgrada u vizuri Zagreba. Kako je jedan od razloga odustajanja od lokacije bio strah dijela zagrebačke političke elite da ce se izgradnjom zgrade izgubiti omiljeno šetalište, Kršnjavi je čak predlagao Schmidtu da zgradu projektira tako da stoji na otvorenim arkadama i „da tako stvori terase i sjenovita mjesta za gospodje, koji liep vidik uživati žele", no kako bi se time cijena njezine izgradnje povisila za 30.000 forinti, od toga se odustalo (SI. 10.). ${ }^{71}$

Nakon što se mjesecima realizacija projekta nije pomaknula s mrtve točke i kada je postajalo sve neizvjesnije hoce li se uspjeti ishoditi zemljište na Griču, početkom 1876., u doba kad su se Kršnjavi, Strossmayer i Bollé intenzivno družili u Rimu, u prvome broju časopisa „Vienac” iz te godine objavljeni su prvi Schmidtovi projekti za zgradu Akademije i Galerije. Radilo se nesumnjivo o pokušaju da se preko njihove atraktivnosti utječe na odluku Gradskoga zastupstva da odobri gornjogradsku lokaciju. Usprkos tekstu, kao i objavi niza članaka u zagrebačkom „Obzoru”, te osobnim zauzimanjima Račkoga, Kršnjavoga i Strossmayera kod političkih velikodostojni-

68 ŠıŠıć, 1928: 379, Rački Strossmayeru, Zagreb, 7.10. 1875 .

69 Šıšıć, 1928: 346, Rački Strossmayeru, Zagreb, 11.4 . 1875.; Šıšıc, 1928: 347, Strossmayer Račkomu, Dakovo, 18.4.1875.; Śıšıc, 1928: 349, Rački Strossmayeru, Zagreb, 23.4.1875

70 HR-AHAZU, XII A 332/7, Kršnjavi Račkom, Beć/ Weidling, 27.6.1875.; Šıšıć, 1928: 377, Strossmayer Raćkom, Đakovo, 2.10.1875.; Šıšıc, 1929: 4, Strossmayer Račkomu, Rim, 15.1.1876.

71 KRŠnJaVI, 1875: 1 

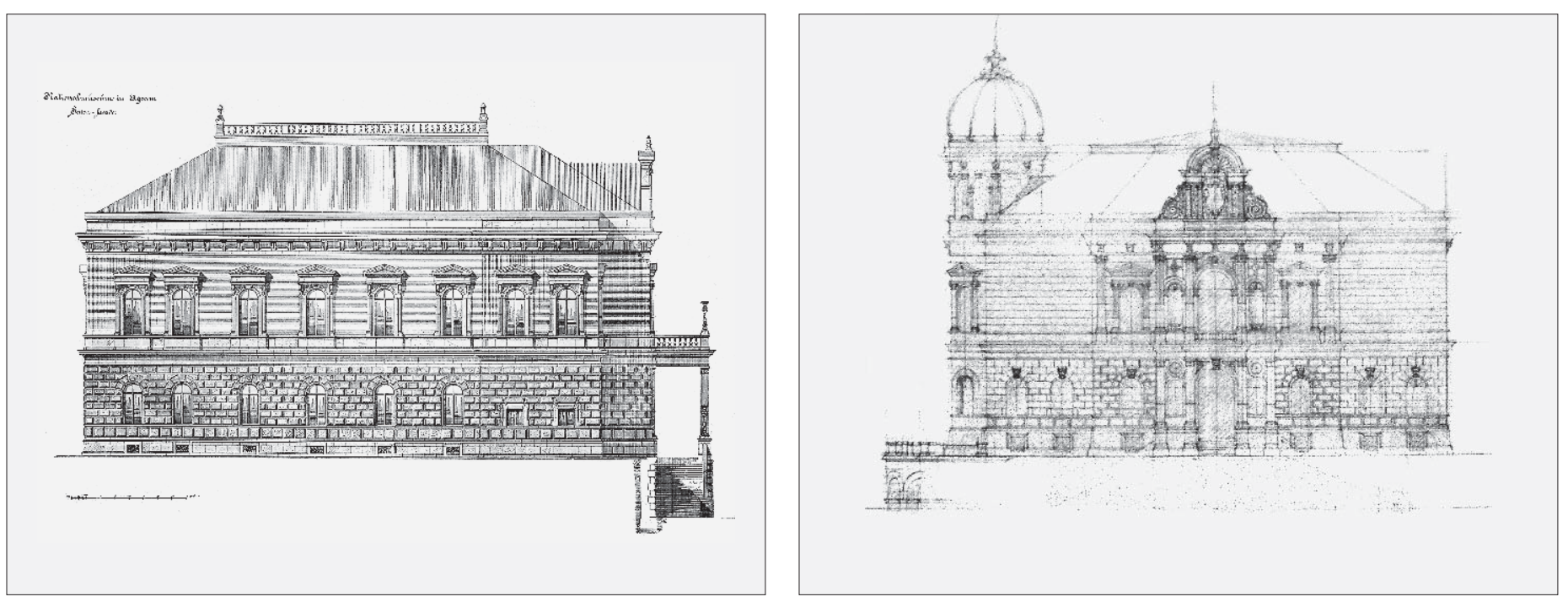

ka, grad je ipak odlučio 10. travnja 1876. da je primjerenije zemljište za izgradnju palače na rubu Zrinskoga trga. ${ }^{72}$ lako se ta odluka pokazala iznimno dalekovidnom, u prvi je mah razočarala i Strossmayera i Račkoga. ${ }^{73}$ Smatrali su je odrazom indolencije i nezainteresiranosti gradskih vlasti za projekt. Naime, u isto je vrijeme i hrvatska vlada odugovlačila s odobravanjem novčane potpore za gradnju, tako da, usprkos svim očekivanjima, osim završenih projekata ni jedan drugi korak nije učinjen prema realizaciji zgrade Akademije.

Ove su okolnosti navele Račkoga da u nekoliko navrata, počevši od vremena kad je Schmidt radio na prvim projektima 1875 . godine $^{74}$ sve do sredine $1876 .^{75}$, predloži Strossmayeru da se ne ide s gradnjom monumentalne građevine, vec 'obične' kuce. Biskup, međutim, koliko se moglo ustanoviti, nikada nije prihvatio tu sugestiju. Stalno je nastojao Akademiji osigurati monumentalnu zgradu, zbog već spomenutog uvjerenja da ce time utjecati na suvremenike kako bi i oni krenuli istim putem te stoga što „Zagreb napreduje, [pa] prema tomu napredku valja da sve ono napreduje, što mu u oči pada". ${ }^{76} \mathrm{Mi}$ jenjanje lokacije palače, a potom i njezine namjene, iziskivalo je, međutim, izradu potpuno novih projekata za tu građevinu u mjesecima koji ce uslijediti.

72 ŠıŠıć, 1929: 13, Rački Strossmayeru, Zagreb, 10.4 . 876.; KNEŻEVIC, 1996: 55

73 Šı̌̌ıć, 1929: 2, Rački Strossmayeru, Zagreb, 11.1.1876. 74 Šıšıc, 1928: 36o, Rački Strossmayeru, Zagreb, 17.6. 1875 .

75 Šıšıć, 1929: 41-42, Rački Strossmayeru, Zagreb, 27.8. 1876.

76 Strossmayer je ovo istaknuo pišuci o potrebi restauracije kapele koja je stajala uz franjevačku crkvu u Zagrebu. [STROSSMAYER, 1875.b: 30]

77 ŠıŠıć, 1929: 13, Rački Strossmayeru, Zagreb, 10.4. 1876.

\section{DRUGI PROJEKT ZA PALAČU AKADEMIJE I GALERIJU SLIKA, 1876.}

\section{SECOND PROJECT FOR THE ACADEMY PALACE AND THE GALLERY OF PAINTINGS, 1876}

Na spomenutoj konferenciji koju je Gradsko poglavarstvo 10. 4. 1876. godine održalo vezano za izgradnju palače Akademije, Franjo Rački složio se naposljetku s lokacijom na Zrinskom trgu, djelomično i stoga što su ga uvjerili da je ona povoljnija, s obzirom na to da bi samo izgradnja temelja na platou Griča stajala dvadeset-trideset tisuca forinti, a ne bi bilo ni mjesta za zgradu vecih dimenzija. ${ }^{77}$

Isu Kršnjavoga ta je odluka iznimno razočarala. Tumačio ju je odrazom neupućenosti u
SL. 8. F. SCHMidt: Projekt za bočno pročelje AKademiJe I GALERIJE SLIKA U ZAGREBU, NEKOLORIRANA I NEPOTPISANA VARIJANTA, 1875.

FIG. 8 F. SCHMIDT: ACADEMY AND THE GALLERY of PAINTINGS IN ZAGREB, Side FACADE, NON-COLOURED AND UNSIGNED VERSION, 1875

SL. 9. F. SCHMidT: SKICA ZA PROČELJE ZGRAdE AKAdEMIJE I GALERIJE SLIKA U ZAGREBU U STILU NJEMAČKE NEORENESANSE S ERKEROM, 1875. (?)

FIG. 9 F. SCHMIDT: ACADEMY BUILDING AND THE GALLERY OF PAINTINGS IN ZAGREB, FACADE IN GERMAN NEO-RENAISSANCE STYLE, WITH BAY WINDOW, SKETCH, 1875 (?)

SL. 10. F. SCHMIDT: TLOCRT I POLOŽAJNI NACRT AKADEMIJE I GALERIJE SLIKA U ZAGREBU, PREVIDENE ZA PLATO GRIČA, 1875 .

FIG. 10 F. SCHMIDT: ACADEMY AND THE GALLERY OF PAINTINGS IN ZAGREB, FLOOR PLAN AND LAYOUT PLAN, PLANNED FOR THE PLATEAU ON GRIČ, 1875

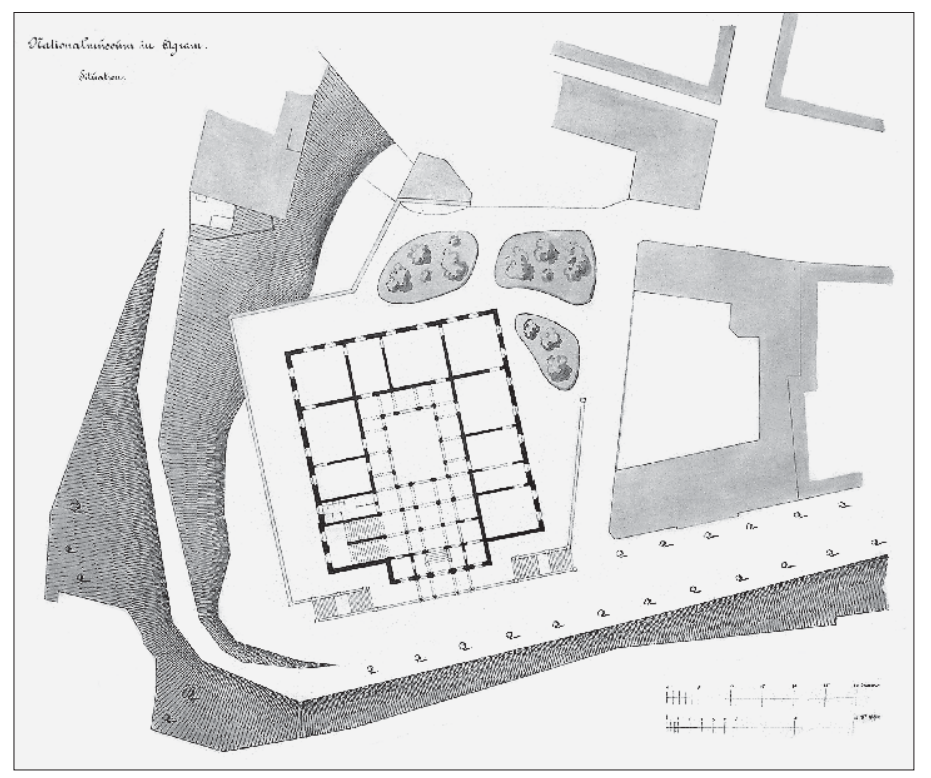




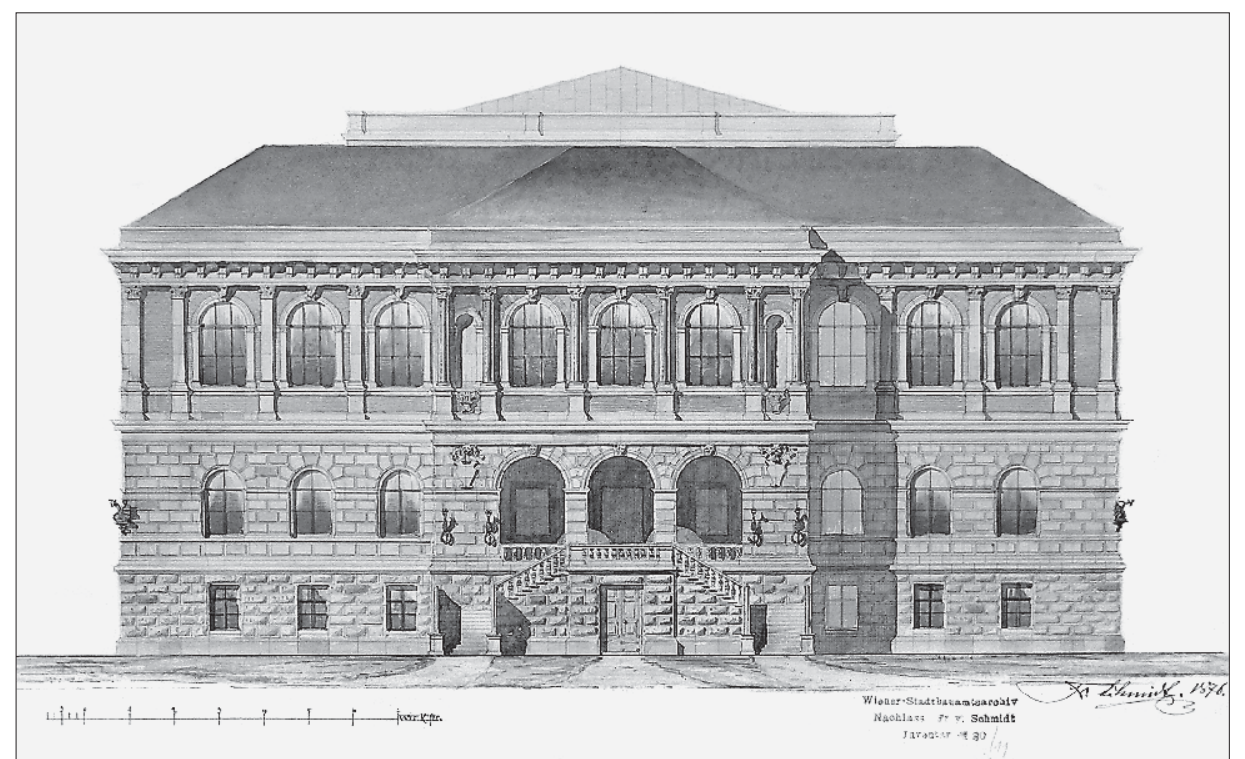

SL. 11. F. SCHMIDT: Projekt ZA GLAVNo PRoČELJE AKAdEMIJE I GALERIJE SLIKA U ZAGREBU, 1876. FIG. 11 F. SCHMIDT: ACADEMY AND THE GALLERY OF PAINTINGS IN ZAGREB, MAIN FACADE, 1876

SL. 12. F. SCHMIDT (?): SKICA GLAVNOGA PROČELJA AKAdEMIJE I GaleriJe SlikA U ZAgRebu, 1876.

FIG. 12 F. SCHMIDT (?): ACADEMY AND THE GALLERY OF PAINTINGS In ZAgREB, MAIN FACADE, SKETCH, 1876 estetska pitanja članova zagrebačkoga poglavarstva: „Galerija slika namienjena je pobuditi ukus i poznavanje ljepote, koji sad u Zagrebu odlučivahu o tom pitanju živili su i ostarili u podpunom estetičnom barbarstvu." 78 Svjestan, međutim, da bi otpor novoj lokaciji palače samo odgodio početak njezine izgradnje, zajedno s Račkim nastojao je uvjeriti Strossmayera da je prihvati. Bez vecega otpora, svjestan situacije, a i zbog želje da što prije počne izgradnja palače, biskup je već sredinom travnja 1876. pristao na novu lokaciju ${ }^{79}$ pa se moralo započeti s izradom novih projekata prilagođenih Zrinskom trgu.

Naručio ih je u ime Akademije Rački tijekom travnja 1876., definirajuci pritom troškove podizanja zgrade na sedamdeset do osamdeset tisuća forinti. ${ }^{80}$ Kao glavni posrednik između Schmidta s jedne te Strossmayera i Račkoga s druge strane, vezano za ovaj projekt sada je već počeo raditi isključivo Bollé. ${ }^{81}$ Sudeći po riječima Kršnjavoga upućenim Račkom („Kako znadete, prečastni gospodine, Šmidt doduše dirigira radnju, ali arhitekt Bollé, njegov učenik, neposredno izradjuje sve osnove”) 82 i Lacku Mrazovicu (,g. Bollé, arhitekt koji ce Šmidtov plan za galeriju izraditi an detail, vratio se je ovih dana u Beč sa dva mjesečnog putovanja po Italiji gdje je poglavito učio detaile za gradnju galerije") ${ }^{83}$ Bolléu se može pripisati i dio autorstva projekta zgrade, iako na svim sačuvanim listovima projekta iz 1876. stoje samo Schmidtovi potpisi.

Prije nego što se završi novi projekt bio je nuždan Bolléov posjet Zagrebu i pregledavanje novoga zemljišta, no smrt arhitektove majke onemogucila ga je da dođe sve do lipnja $1876 .{ }^{84}$, nakon čega je tek, čini se, započeo intenzivniji rad na novim projektima za Akade-

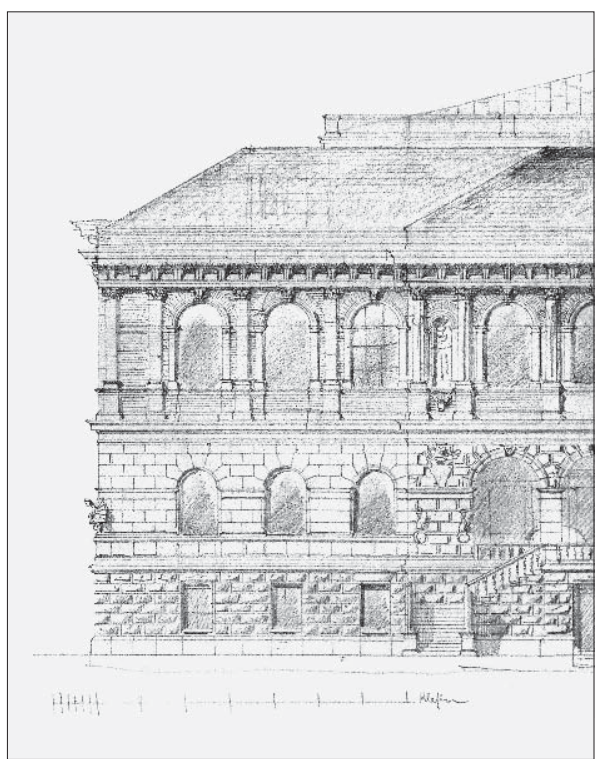

miju. Kako je Bollé pri izvidu terena procijenio da ce ukupni troškovi gradnje biti daleko veći, između 120 i 140 tisuca forinti, na početak radova još se nije moglo ni misliti. ${ }^{85}$

U trenutku kad je zemljište na Zrinskom trgu predano Akademiji za izgradnju palače (9. 6. 1876.), usprkos svim požurivanjima Schmidta, ${ }^{86}$ možda i zbog nejasne novčane situacije, druga serija projekta još uvijek nije bila gotova. ${ }^{87}$ Završena je do početka kolovoza 1876 . i njome je definitivno bilo predviđeno da ce izgradnja stajati 120.000 forinti. ${ }^{88}$ Ova je svota odmah postala osnovni problem pri realizaciji projekta. Rački je smatrao da vlada nece odobriti dovoljnu pomoć kako bi se mogla izvesti ovako reprezentativna zgrada. ${ }^{89}$ Strossmayer, međutim, nije htio odustati od monumentalne građevine. U trenutku kad se počelo raditi na novim projektima, ponovno je naglasio ulogu koju bi zgrada Akademije i Galerije trebala imati u zagrebačkoj arhitekturi „Ova sgrada valja da bude uzorna. To je početak koji ce led u Zagrebu probiti." $90 \mathrm{~S}$ obzirom na ova očekivanja, ne čudi reprezen-

78 HR-AHAZU, XI A/Krš. I. 16, Kršnjavi Strossmayeru, Rim, 19.4.1876.

79 Šıšıć, 1929: 14, Strossmayer Račkomu, Đakovo, 15.4. 1876.

80 Šıšıc, 1929: 14, Rački Strossmayeru, Zagreb, 26.4 1876.

81 NAD, CGO, br. 16-1876., Schmidt Strossmayeru, Beč, 23.4.1876.

82 HR-AHAZU, XII A 332/3, Kršnjavi Račkom, Rim, 22.1. 1876. (Pismo je datirano 22.1.1875., ali oćito je rijeć o pogreści u pisanju.)

83 TARTAGLIA Kelemen, 1973: 218; Kršnjavi Mrazovicu, s. d., s. l., Rim (?), sredina travnja 1876.

84 NAD, CGO, br. 47, Schmidt Strossmayeru, Beć, 24.5. 1876. 


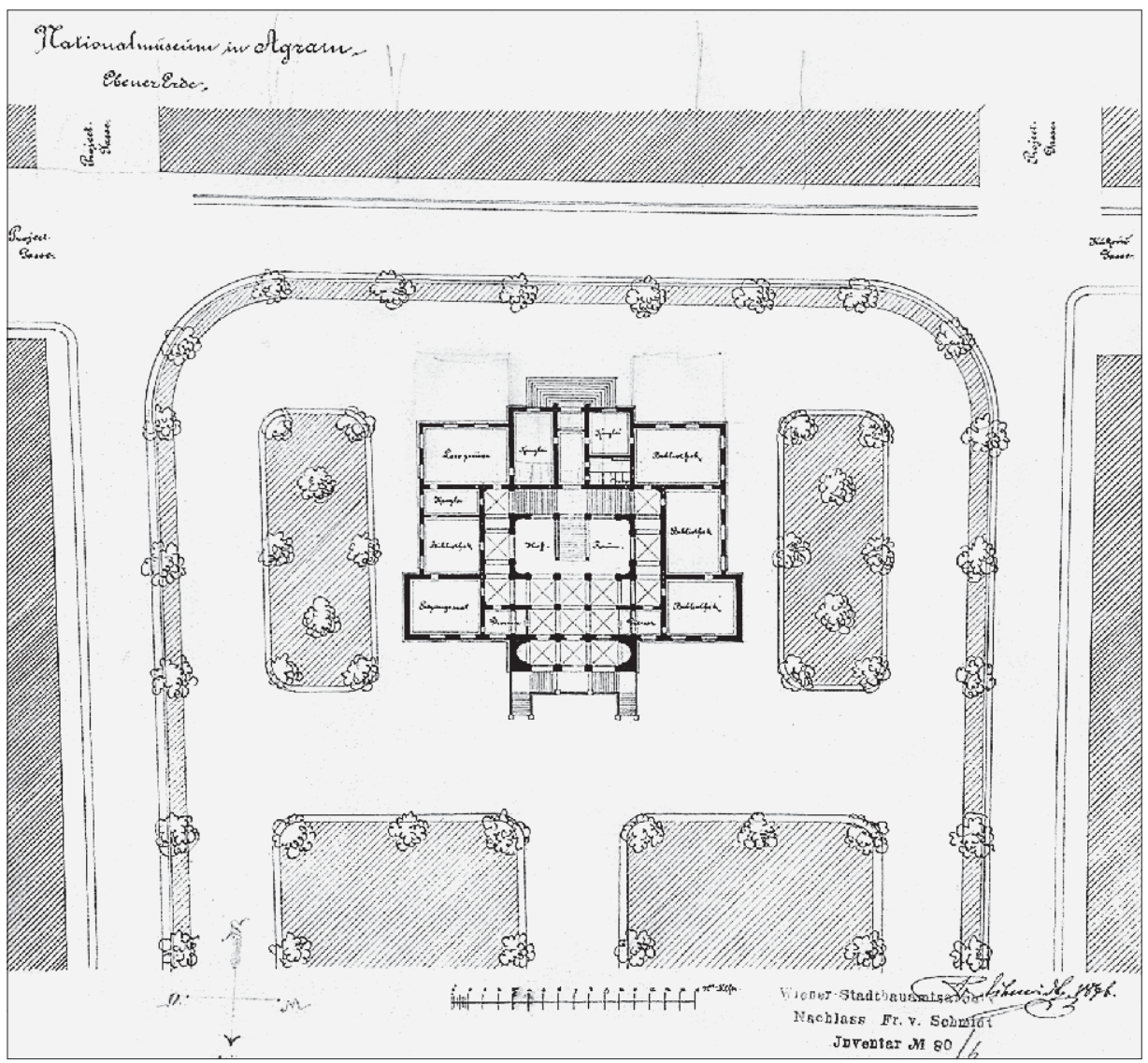

tativnost (i) drugoga projekta za palaču Akademije (SI. 11.).

Projekt iz 1876. koji dosad, koliko je poznato, nije analiziran u stručnoj literaturi ${ }^{11}$, sačuvan je u trima listovima (glavno pročelje, te tlocrti prizemlja i prvoga kata) u ostavštini Friedricha Schmidta u Muzeju grada Beča. U Nadbiskupijskom arhivu u Zagrebu čuvaju se dva tlocrta kao i polovica skice za projekt glavnoga pročelja (Sl. 12.), koja je gotovo identična rješenju glavnoga pročelja sačuvanoga u Beču (jedina se veća razlika uočava u rješenju niša na rizalitu glavnoga pročelja).

85 ŠıŠıć, 1929: 28, Strossmayer Račkomu, Đakovo, 13.6 1876.; Šıšıc, 1929: 28-29, Rački Strossmayeru, Zagreb, 19.6.1876.

86 ŠıŠıć, 1929: 24, Rački Strossmayeru, Zagreb, 12.5. 1876.

87 KNEŽEVIĆ, 1996: 55

88 Šıšıc, 1929: 37-38, Strossmayer Račkomu, Weidling, 6.8.1876.

89 Šıšıć, 1929: 41-42, Rački Strossmayeru, Zagreb, 27.8.1876.

$90 \mathrm{HR}-\mathrm{HDA}-804, \mathrm{KI}$, kut. 4, III/3, Strossmayer Kršnjavom, Đakovo (?), 16.4.1876.

91 Pročelje je objavljeno, bez analize, u: HAIKO, KASSALMIKULA, 1991: 148-149

92 HR-AHAZU, XII A 332/13, Kršnjavi Račkom, Rim, 19.4. 1876. državaju samo stilsko polazište, dok rješenje pročelja, a djelomično i prostorno ustrojstvo građevine, bitno mijenjaju. U početku rada na drugom projektu, kada mu se još činilo da neće biti potrebne znatnije promjene, Bollé je jasno definirao da ce se u novome projektu ispustiti postojece supstrukcije i da ce se podici pian tereno jer nisu potrebni na ravnome terenu Zrinskoga trga. Kršnjavi mu je tada sugerirao da prostore Galerije na prvom prihvaceno. ${ }^{22}$

Rješenje pročelja po drugome projektu iznimno je atraktivno. Schmidt se (u suradnji s Bolléom) ponovno odlučuje na korištenje triju tipova raščlambe - grubo obrađeni kamen namjeravao je postaviti na pročelje razizemlja, glatko obrađeni kamen predvidio je za visoko prizemlje, a kombinaciju kamena i fasadne opeke za pročelje prvoga kata. Središnji, rizalitno istaknuti dio pročelja bio bi na prvom katu naglašen prislonjenim stupovima, dok bi bočne dijelove glavnoga pročelja raščlanjivali pilastri. Korintski slog i dalje je korišten kao polazište. Na zidu uz lukove glavnoga ulaza nalazile bi se svjetiljke izvedene od kovana željeza, iznad kojih bi se nalazila polja vjerojatno namijenjena za grbove,
U odnosu na prvi projekt Schmidt i Bollé zakatu otvori većim prozorima, što je doista i
SL. 13. F. SCHMIDT: TLOCRT PRIZEMLJA AKADEMIJE I GALERIJE SLIKA U ZAGREBU S PRIJEDLOGOM SMJEŠTAJA ZGRADE U JUŻNOM DIJELU ZRINSKOGA TRGA, 1876.

FIG. 13 F. SCHMIDT: ACADEMY AND THE GALLERY OF PAINTINGS IN ZAGREB, GROUND-FLOOR PLAN WITH A SITE PROPOSAL FOR THE BUILDING ON THE SOUTHERN SIDE OF ZRINSKI SQUARE, 1876

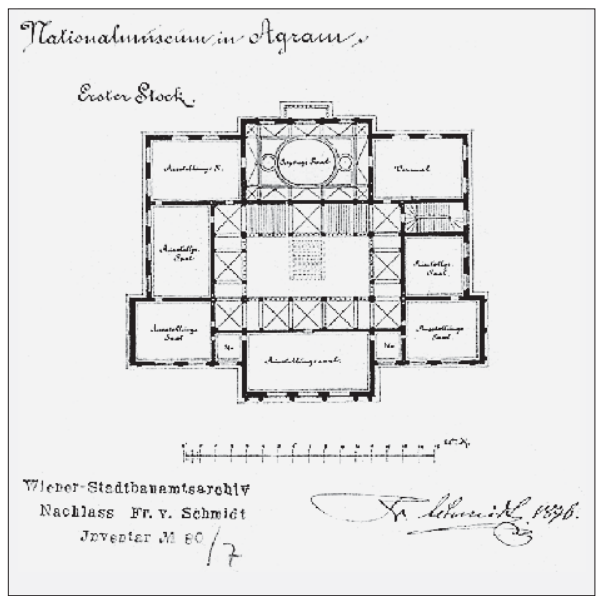

SL. 14. F. SCHMIDT: TLOCRT PRVOGA KATA AKADEMIJE I GALERIJE SLIKA U ZAGREBU, 1876.

FIG. 14 F. SCHMIDT: ACADEMY AND THE GALLERY OF PAINTINGS IN ZAGREB, FIRST-FLOOR PLAN, 1876 
dok su na uglovima glavnoga pročelja planirani zanimljivi držači baklji (njem. Fackelhalter), koje Schmidt direktno preuzima iz renesansne arhitekture ${ }^{93}$, vjerojatno nadahnut Bolléovim crtežima iz Italije. Pretpostavlja se da se planiralo postavljanje skulptura u niše prvoga kata, no nikakav ikonografski program ni u ovome slučaju nije bio specificiran.

I na drugom projektu Schmidt i Bollé zadržali su ideju da se u prizemlju zgrade nalaze prostori namijenjeni uredima i knjižnici Akademije, dok bi se na prvom katu nalazila Galerija i svečana soba koja bi bila posebno bogato ukrašena. Središnji bi prostor opet činio staklom natkriven atrij, koji bi, međutim, dijelom bio ispunjen monumentalnim stubištem. Neobično rješenje može se iščitati samo iz tlocrta, jer se presjeci iz serije projekata iz 1876. nisu mogli pronaci (SI. 13.-14.).

Projekt iz 1876. oslanja se na uobičajena rješenja za muzejske zgrade 19. stoljeca. Osobito podsjeca na građevine vec spomenute $u$ ovome tekstu - Klenzeovu minhensku Pinakoteku94 i Semperovu drezdensku galeriju, no stanovite se sličnosti uočavaju i sa zgradom École des beaux-arts Félixa Dubana u Parizu (1832.-1870.) ${ }^{95}$, koju je Schmidt mogao poznavati jer je aktivno sudjelovao na Svjetskoj izložbi u Parizu 1867. ili preko arhitektonskih časopisa. Dakako, uvijek se postavlja pitanje u kolikoj su se mjeri svi ovi arhitekti u svojim projektima oslanjali na potencijalne zajedničke uzore iz arhitekture 15. i 16. stoljeca.

Da je izvedena prema ovome projektu, palača Akademije i Galerije bila bi bolje proporcionirana negoli je današnja zgrada. Privlačnosti rješenja pridonosi i predviđena upotreba kamena na pročeljima i prizemlja i prvoga kata, kao i elegantno rješenje ulaza. S obzirom na to da bi bila znatno niža, istodobno bi zasigurno bila manje prisutna u slici grada.

\section{TREĆI PROJEKT ZA PALAČU AKADEMIJE, GALERIJU SLIKA I ARHEOLOŠKI ODJEL NARODNOGA MUZEJA, 1877.}

\section{THIRD PROJECT FOR THE ACADEMY PALACE, THE GALLERY OF PAINTINGS, AND THE ARCHAEOLOGICAL DEPARTMENT OF THE NATIONAL MUSEUM, 1877}

Sudeci po sačuvanom tlocrtu prizemlja Akademije prema projektu iz 1876. (SI. 13.), Schmidt je predvidio podizanje zgrade na sredini južnoga dijela Zrinskoga trga, a ne na njegovu rubu, koje je i Kršnjavi ocjenjivao kao pogodnije mjesto ${ }^{96}$, vjerojatno stoga što je mislio da ce time doći više do izražaja. U trenutku kad je ovaj projekt bio završen, još uvijek, međutim, nije bilo do kraja definirano pitanje smještaja palače. Lokacija na rubu trga, na kojoj ce palača na kraju biti i podignuta, predstavljala je daleko skuplje rješenje jer se trebalo pristupiti otkupu privatnoga zemljišta.

Konačna odluka o smještaju palače donesena je tek 6. siječnja 1877., kad je Gradsko poglavarstvo pristalo izdvojiti 40.000 forinti za otkup zemljišta. ${ }^{97}$

Uz pitanje lokacije, drugo ključno pitanje koje se protezalo od nastanka ideje o gradnji palače do početka njezine izgradnje odnosilo se na institucije koje bi trebala udomljivati. Uz Akademiju i Galeriju, Kršnjavi je isprva htio da se $u$ istoj zgradi nađe i prostorija za izlaganje djela umjetničkog obrta, zatim Obrtnička muška i ženska škola, prostorija za zbirku bakroreza te knjiga o umjetnosti i umjetničkom obrtu, prostorija za periodične izložbe Društva umjetnosti, pa čak i prostorija namijenjena prodavanju umjetnina i obrtnina. S druge strane, smatrao je da bi Akademija za svoje urede trebala sagraditi posebnu zgradu, čime bi se dobila jedna građevina namijenjena samo za muzej i izložbe (a time bi i on imao vecu slobodu u djelovanju). ${ }^{8}$

Smjestiti sve institucije koje je Kršnjavi priželjkivao pod krov jedne zgrade pokazat ce se nemogucim, no na kraju ce se ipak uz urede Akademije i Galeriju u palači na Zrinskom trgu smjestiti Arheološki odjel Narodnoga muzeja. Zamisao o zajedničkom skućivanju ovih triju institucija rodila se paralelno s rađanjem ideje o samoj palači, tijekom 1875. i od samih početaka biskup Strossmayer nije imao ništa protiv nje. ${ }^{99}$ Ponovno ce se iskristalizirati u jesen 1876. godine. Nakon što godinama Akademija nije uspjela dobiti sredstva od vlade za podizanje svoje zgrade Sabor je konačno odobrio čak 80.000 forinti za tu svrhu, više negoli su Rački i Strossmayer očekivali. U službenom dopisu Akademiji od 5. 12. 1876. godine vlada je, međutim, uvjetovala isplatu tog iznosa ustupanjem nekadašnjega Narodnog doma u Opatičkoj 18 (u kojem su se tada nalazili uredi Akademije) Odjelu za pravosuđe i smještanjem u novu zgradu Akademije i Arheološkoga odjela Narodnoga muzeja. ${ }^{100}$

93 BURCKHARDT, 1912: 305

94 Osobito je slično rješenje prvoga kata istočne fasade Pinakoteke i Schmidtovo rješenje najvišega kata palače Akademije. Pogledati: ButTLAR, 2014: 247-265

95 Pogledati: LeVINE, 2018: 495-499

96 HR-AHAZU, XII A 332/3, Kršnjavi Račkom, Rim, 22.1. 1876. (Pismo je datirano 22.1.1875., ali oćito je rijeć o pogrešci u pisanju.)

97 KNEŻEVIC, 1996: 55-60

98 HR-AHAZU, XII A 332/6, Kršnjavi Račkom, Weidling, 8.6.1875.; DULIBIĆ, PASINI TRŽEC, 2018: 274

99 Šıšıć, 1928: 376, Strossmayer Račkomu, Đakovo, 28. 9.1875 .

100 HR-HDA-804, KI, kut. 4, III/3, Strossmayer Kršnjavom, Đakovo (?), 28.9.1876.; Šıšıc, 1929: 71, Racki Strossmaye- 


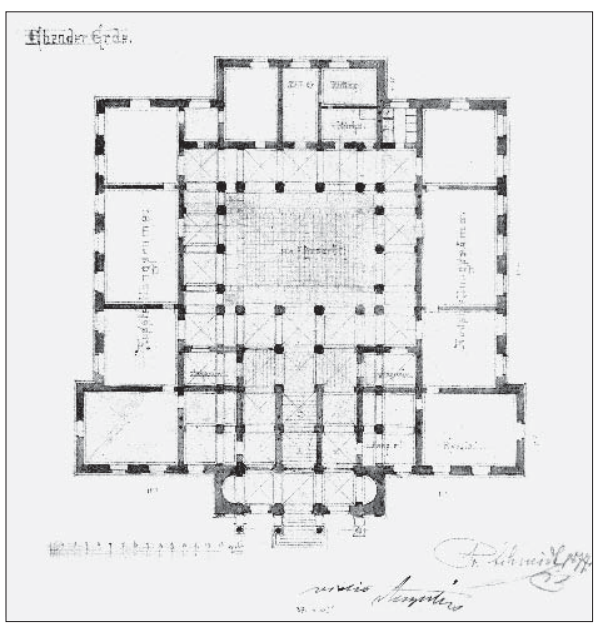

Kako ni prvim ni drugim Schmidtovim projektom nije bilo predviđeno da ova institucija bude udomljena zajedno s Akademijom i Galerijom, moralo se pristupiti izradi potpuno novoga projekta. ${ }^{101}$ Začudo, novi je projekt bio u osnovnim crtama iznimno brzo završen - već do veljače $1877 . .^{102}$ I njega je Schmidt radio u suradnji s Bolléom. ${ }^{103}$ Odmah nakon što je poslan u Zagreb Akademija ga dostavlja vladi ${ }^{104}$ koja ga odobrava već 19 . veljače 1877. ${ }^{105}$ lako se Bolléu isprva činilo da se može zadržati prijašnje rješenje za palaču ${ }^{106}$, naposljetku se ipak moralo pristupiti izradi potpuno novoga projekta. Stil građevine, dakako, ostaje isti - „renaissanca XVI. vieka” ${ }^{107}$, pojedini detalji raščlambe također, ali zgrada sada dobiva cijeli jedan novi kat, i to za osiguravanje dovoljnog prostora za izlaganje arheoloških nalaza.

Projekt odobren u veljači 1877. nije, međutim, još uvijek bio izvedbeni. Zapravo, dosad nije bio poznat jer su listovi toga projekta (u dvije međusobno srodne, ali ne posve istovjetne varijante) sačuvani u privatnoj zbirci g. Jure Gašparca u Zagrebu i u Muzeju grada Beča.

Projekt za glavno pročelje koji se čuva u Muzeju grada Beča bez ikakve je sumnje onaj

ru, Zagreb, 11.11.1876. HR-HDA-804, KI, kut. 4, III/2, Rački Kršnjavom, Zagreb, 11.12.1876. HORVAT, 1925: 218; DULIBIC, PASINI TRŻEC, 2018: 280

101 ŠıŠıC, 1929: 71, Rački Strossmayeru, Zagreb, 11.11. 1876; HORVAT, 1925: 219

102 NAD, CGO, br. 32-1877., Schmidt Strossmayeru, Beć, 27.1.1877

103 NAD, CGO, br. 32-1877, Bollé Strossmayeru, Beč, 27. 1.1877 .

104 KNEŻEVIĆ, 1996: 61

105 Horvat, 1925: 219; Šıšıć, 1929: 91, Rački Strossmayeru, Zagreb, 23.2.1877.

106 Dulibić, PASINI TRŽEC, 2018: 280

$107^{\star \star \star} 1877 . \mathrm{a}: 3$

108 HORVAT, 1925: 219

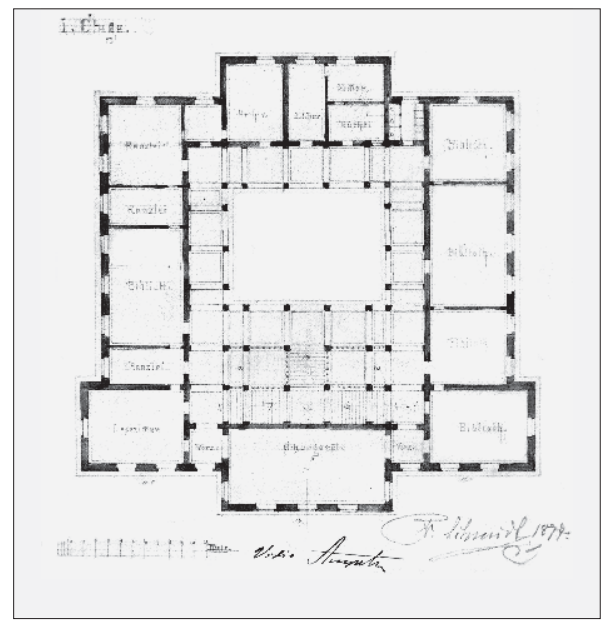

koji je Schmidt poslao na uvid i odobrenje jer ga je ovjerio Juraj Augustin, tadašnji predstojnik Gradjevnog odsjeka Unutarnjeg odjela Hrvatske zemaljske vlade (SI. 18.). On se razlikuje u pojedinim detaljima u odnosu na rješenje na koloriranom projektu, koji je vjerojatno poslan biskupu Strossmayeru na uvid, a koji se čuva danas u zbirci g. Gašparca, i to ponajprije po načinu raščlambe prizemlja (SI. 1.). Prema koloriranoj varijanti bilo je predviđeno postavljanje drukčijeg tipa rustike ispod prozora, lukovi prozora bili bi naglašeni ključnim kamenovima, a ugao rizalitno istaknutog središnjega dijela pročelja bio bi zaključen pilastrima, dok je po nekoloriranoj verziji Schmidt predvidio postavljanje pilastara. Obje su predviđale, kao i projekt iz 1876., postavljanje takozvanih nosača baklji na uglovima (SI. 15.-17.).

\section{IZVEDBENI PROJEKT}

\section{ZA PALAČU AKADEMIJE, GALERIJE I ARHEOLOŠKOG ODJELA \\ NARODNOGA MUZEJA, 1877.}

\section{DETAILED TECHNICAL DESIGN FOR THE ACADEMY PALACE, THE GALLERY, AND THE ARCHAEOLOGICAL DEPARTMENT OF THE NATIONAL MUSEUM, 1877}

Na osnovi Schmidtova projekta poslanoga vladi u veljači 1877. godine, troškovnik za izgradnju palače sastavio je inženjer grada Zagreba Rupert Melkus, koji je potom, na molbu Akademije, provjerio Schmidt. Osim što je trebao provjeriti troškovnik, Schmidt je zamoljen i da prema primjedbama Akademije (vjerojatno samoga Račkoga) unese dodatne promjene u projekt, „koje su smjerale za tim, da akademijska palača bude što jeftinija, ne dirajuc ipak u njezinu čvrstoć i ljepotu”. ${ }^{108}$ Ta je molba inicirala nastanak izvedbenog

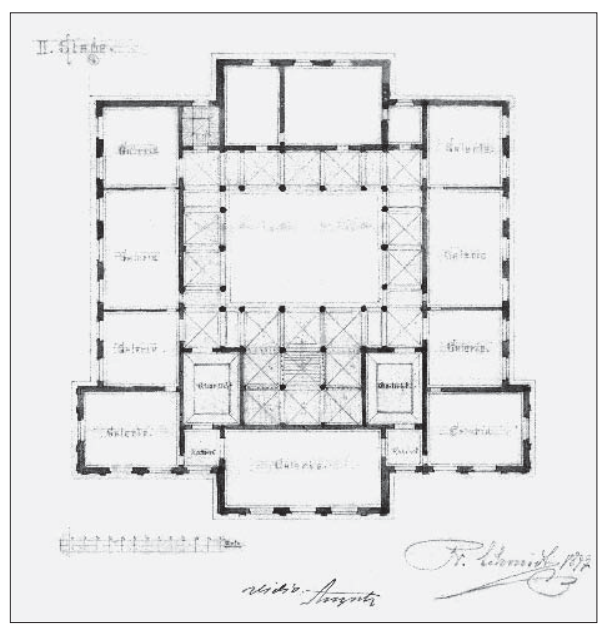

SL. 15. F. SCHMIDT: TLOCRT PRIZEMLJA (NAMIJENJENOGA ARHEOLOŠKOM ODJELU NAROdNOGA MUZEJA) PREMA PROJEKTU IZ VELJAČE 1877.

FIG. 15 F. SCHMIDT: GROUND-FLOOR PLAN (INTENDED FOR THE ARCHAEOLOGICAL DEPARTMENT OF THE NATIONAL MUSEUM) ACCORDING TO THE DESIGN FROM FEBRUARY, 1877

SL. 16. F. SCHMIDT: TLOCRT PRVOGA KATA (NAMIJENJENOGA UREDIMA AKADEMIJE) PREMA PROJEKTU IZ VELJAČE 1877. FIG. 16 F. SCHMIDT: GROUND-FLOOR PLAN (INTENDED FOR THE ACADEMY'S OFFICES) ACCORDING TO THE DESIGN FROM FEBRUARY, 1877

SL. 17. F. SCHMIDT: TLOCRT DRUGOGA KATA (NAMIJENJENOGA GALERIJI SLIKA) PREMA PROJEKTU IZ VELJAČE 1877.

FIG. 17 F. SCHMIDT: SECOND-FLOOR PLAN (INTENDED FOR THE GALLERY OF PAINTINGS) ACCORDING TO THE DESIGN FROM FEBRUARY, 1877 

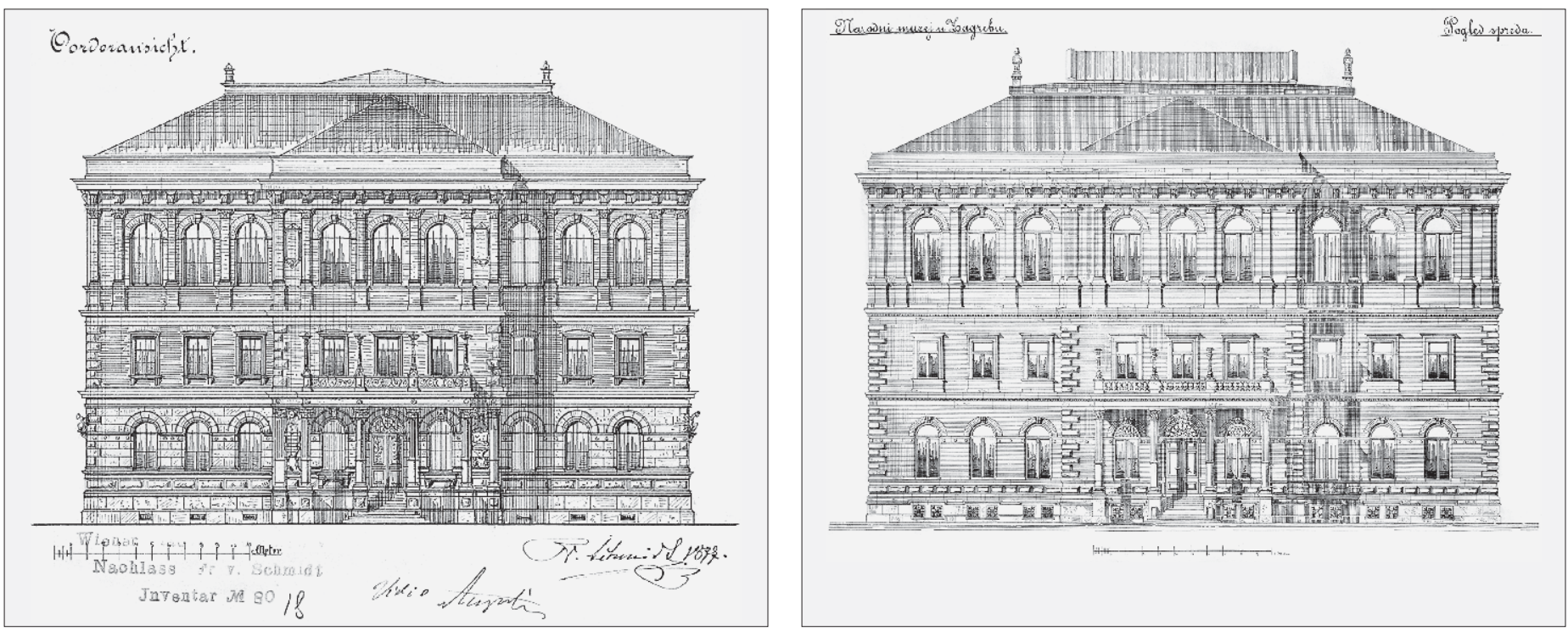

SL. 18. F. Schmidt: Projekt Za glavno Proćelje zgrade AKADEMIJE, ARHEOLoŠKog odjela NaRodnoga MUZEja I GALERIJE SLIKA U ZAGREBU, 1877., NEKOLORIRANA VARIJANTA FIG. 18 F. SCHMIDT: ACADEMY, ARCHAEOLOGICAL Department of the National Museum and the Gallery OF PAINTINGS IN ZAGREB, MAIN FACADE, NON-COLOURED VERSION, 1877
SL. 19. F. SCHMIDT: IZVEDBENI PROJEKT ZA GLAVNO PROČELJE ZGRADE AKADEMIJE, ARHEOLošKog ODJELA NAROdNOGA MUZEJA I GALERIJE SLIKA U ZAGREBU, SVIBANJ-LIPANJ 1877.

FIG. 19 F. SCHMIDT: DETAILED TECHNICAL DESIGN

FOR THE MAIN FACADE OF THE ACADEMY BUILDING, THE Archaeological Department of the National Museum, AND the Gallery of Paintings In Zagreb, MAY-June 1877
109 Izvedbeni projekt sačuvan je u nekoliko institucija - u Kabinetu za arhitekturu i urbanizam HAZU-a [MARTINČıC, 2007: 66-69], Arhivu HAZU-a [HR-AHAZU, fototeka V-23], privatnoj zbirci J. Gašparca, Muzeju grada Beča. Bio je izlożen na izlożbi: JAŠO, PAIĆ-VUKIĆ, 2011. Objavljen je u: ANTOLEC, 1882. te u gotovo svim kasnijim tekstovima vezanim uz povijest JAZU-a/HAZU-a ili Strossmayerove galerije.

110 NAD, CGO, br. 57-1877, Bollé Strossmayeru, 22.3.1877.

111 NAD, CGO, br. 74-1877, Schmidt Strossmayeru, Beć, 9.4.1877.; AHAZU XII A 645/1, Schmidt Račkomu, Beć, 12.4.1877.; ŚIśı́́, 1929: 102, Rački Strossmayeru, Zagreb, 18.4.1877.

112 NAD, CGO, br. 125-1877, Schmidt Drohojovskom, Beč, 29.5.1877.

$1133^{\star \star \star} 1877 \cdot b: 3$

ZT. 1 . SCHMIDT: IZVEDBENI PROJEKT ZA BOCNU FASADU MUZEJA I GALERIJE SLIKA U ZAGREBU, SVIBANJ-LIPANJ 1877. FIG. 21 F. SCHMIDT: DETAILED TECHNICAL DESIGN FOR THE SIDE FACADE OF THE ACADEMY BUILDING, THE ARCHAEOLOGICAL DEPARTMENT OF THE NATIONAL MUSEUM, and the Gallery of Paintings In Zagreb, May-June 1877

114 HR-AHAZU, XII A 332/19, Kršnjavi Račkom, Beč, 18.12. 1876.

115 Šıšı́c, 1929: 117, Rački Strossmayeru, Zagreb, 13.7. 1877. O Schmidtovom posjetu Zagrebu u: ${ }^{\star \star \star} 1877$.c: 4
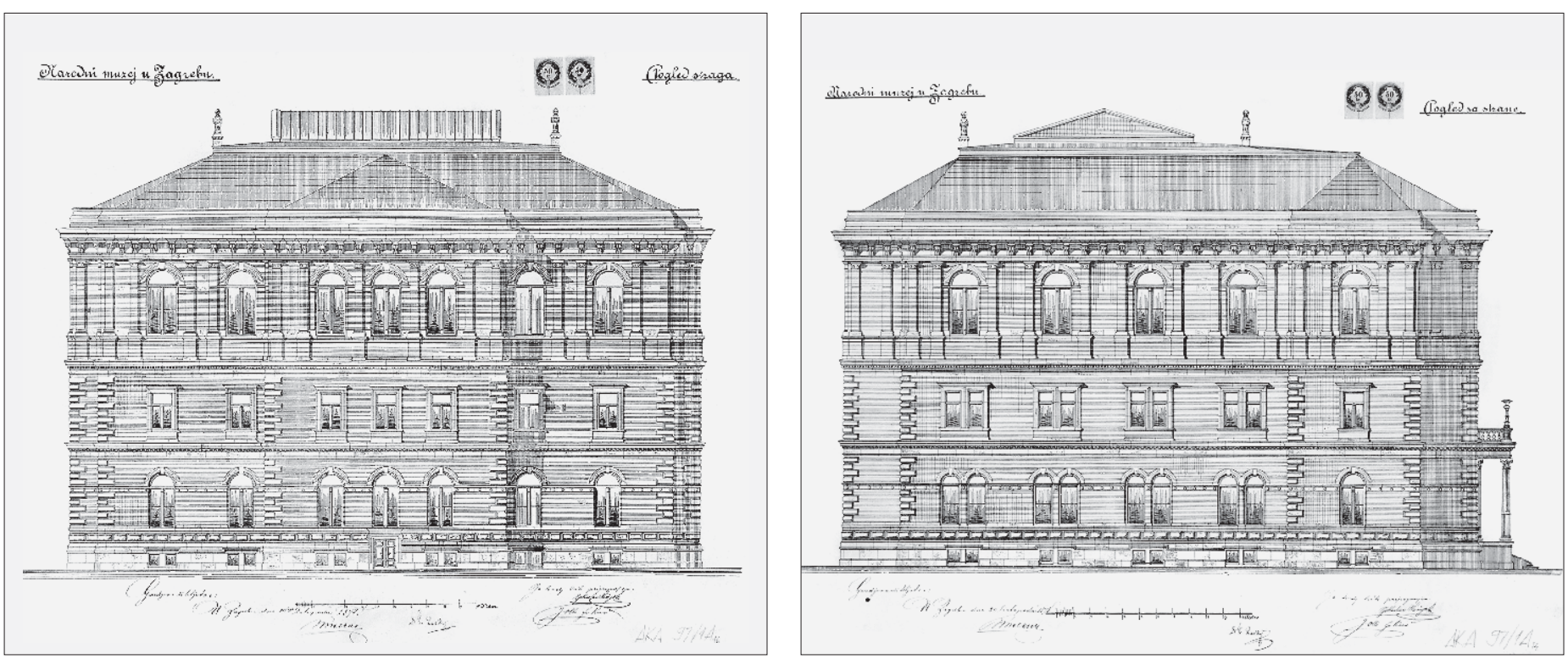


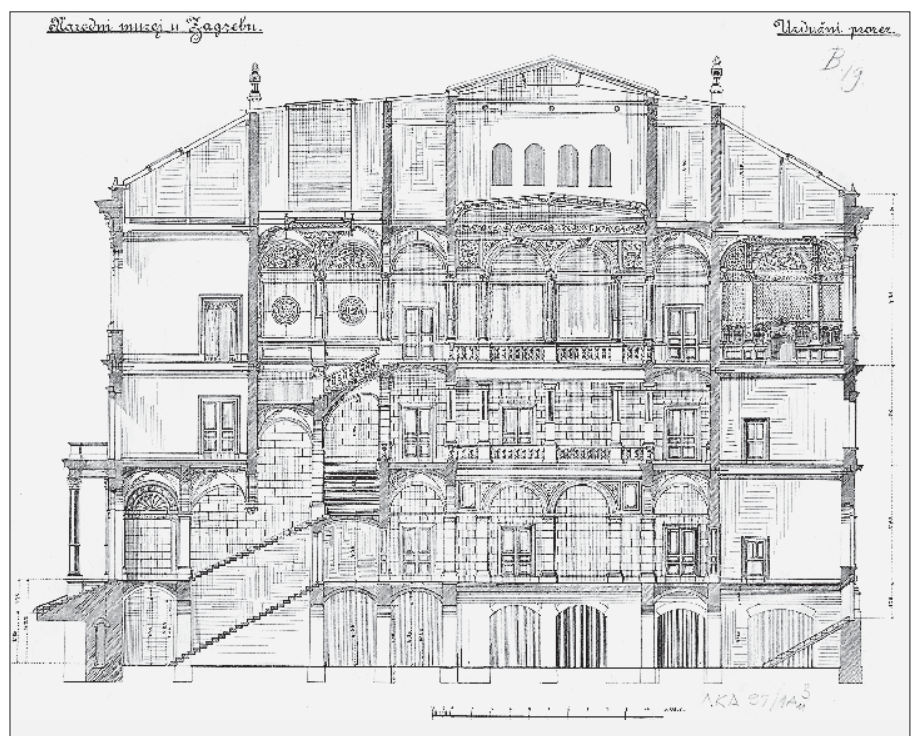

projekta (SI. 19.-26.). Riječ je zapravo o trećoj varijanti trecega projekta za Akademiju, koja se posebno analizira, s obzirom na to da je po njoj zgrada uvelike izgrađena. ${ }^{109}$

I rad na tome projektu dobro je dokumentiran. Nove skice preradio je Bollé do kraja ožujka $1877 .{ }^{110}$, sredinom travnja Schmidt je potom poslao Melkusu projekte za pročelja te presjek i tlocrt ${ }^{111}$, dok je krajem svibnja iste godine završio definitivne projekte. ${ }^{112} \mathrm{O}$ tome su odmah javile i zagrebačke novine, ističući

SL. 24. F. SCHMidT: TLOCRT PRIZEMLJA (NAMIJENJENOGA ARHEOLOŠKOM ODJELU NARODNOGA MUZEJA) PREMA PROJEKTU IZ SVIBNJA/LIPNJA 1877.

FIG. 24 F. SCHMIDT: GROUND-FLOOR PLAN (INTENDED FOR THE ARCHAEOLOGICAL DEPARTMENT OF THE NATIONAL MUSEUM) ACCORDING TO THE DESIGN FROM MAY/JUNE 1887

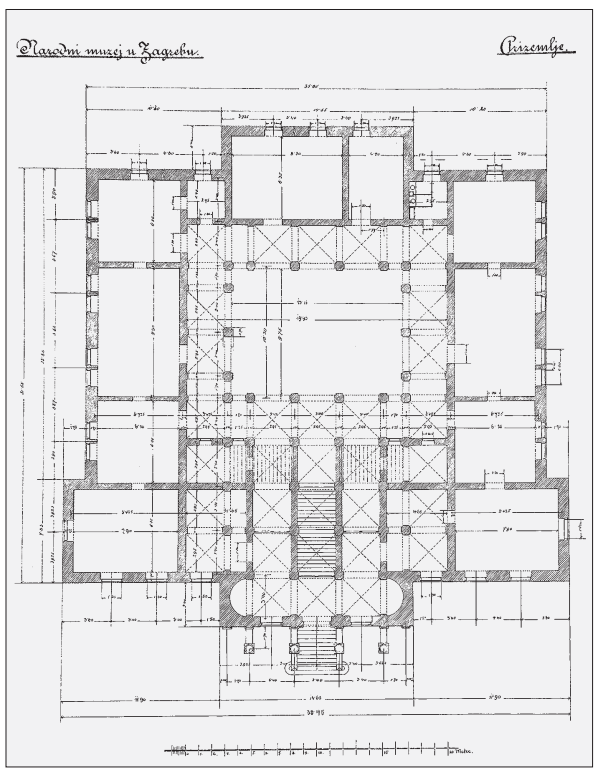

pritom da je „osnova prekrasna i ako se točno izvede, bit ce akademička palača najljepša sgrada u našoj zemlji”. ${ }^{113}$

U tom se trenutku pojavio novi problem. Obistinilo se, kako je Kršnjavi upozoravao Račkoga, da ce Schmidt podcijeniti troškove izgradnje. ${ }^{114}$ lako je Rački od Schmidta tražio da oni ne prijeđu $120.000-130.000$ forinti, ispostavilo se, pri Schmidtovom posjetu Zagrebu u srpnju 1877., da ce zgrada po novim projektima stajati najmanje 220.000 forinti. ${ }^{115}$

SL. 25. F. SCHMIDT: TLOCRT PRVOGA KATA (NAMIJENJENOGA UREDIMA AKADEMIJE) PREMA PROJEKTU IZ SVIBNJA/LIPNJA 1877.

FIG. 25 F. SCHMIDT: FIRST-FLOOR PLAN

INTENDED FOR THE ACADEMY'S OFFICES) ACCORDING TO THE DESIGN FROM MAY/JUNE 1877

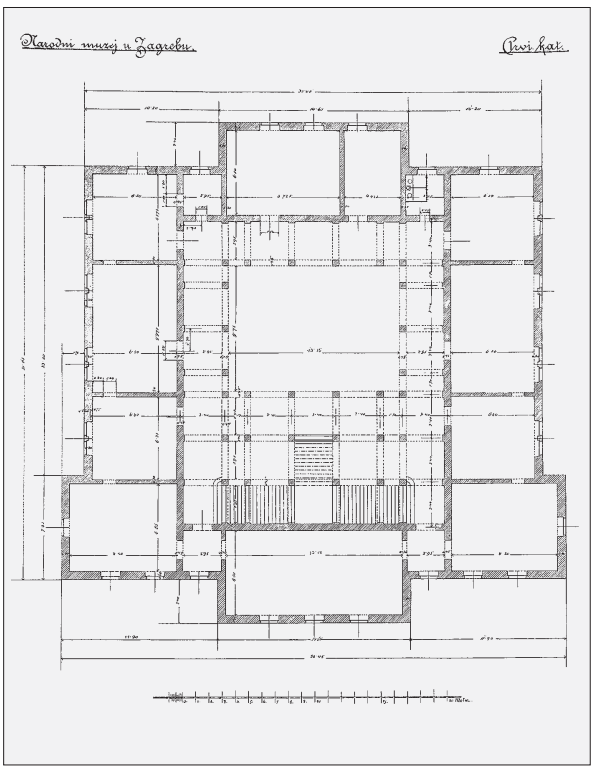

SL. 22. F. SCHMidT: UZduŻNI PRESJEK ZgRAde AKAdemiJe, ARHEOLOŠKOG ODJELA NARODNOGA MUZEJA I GALERIJE SLIKA U ZAGREBU, SVIBANJ-LIPANJ 1877.

FIG. 22 F. SCHMIDT: ACADEMY BUILDING,

the ARCHAEOLOGICAL DePARTMENT OF THE NATIONAL Museum AND the Gallery of PaInTINGS IN Zagreb, LONGITUDINAL SECTION, MAY-JUNE 1877

SL. 23. F. SCHMIDT: PopReČnI PRESJEK ZgRAde AKADEMIJE, ARHEOLOŠKOG ODJELA NARODNOGA MUZEJA I GALERIJE SLIKA U ZAGREBU, SVIBANJ-LIPANJ 1877.

FIG. 23 F. SCHMIDT: ACADEMY BUILDING, THE ARCHAEOLOGICAL DePARTMENT OF THE NATIONAL MUSEUM AND THE GALLERY OF PAINTINGS IN ZAGREB, CROSS-SECTION, MAY-JUNE 1877

SL. 26. F. SCHMIDT: TLOCRT DRUGOGA KATA (NAMIJENJENOGA GALERIJI SLIKA) PREMA PROJEKTU IZ SVIBNJA/LIPNJA 1877.

FIG. 26 F. SCHMIDT: SECOND-FLOOR PLAN

(INTENDED FOR THE GALLERY OF PAINTINGS) ACCORDING TO THE DESIGN FROM MAY/JUNE 1877

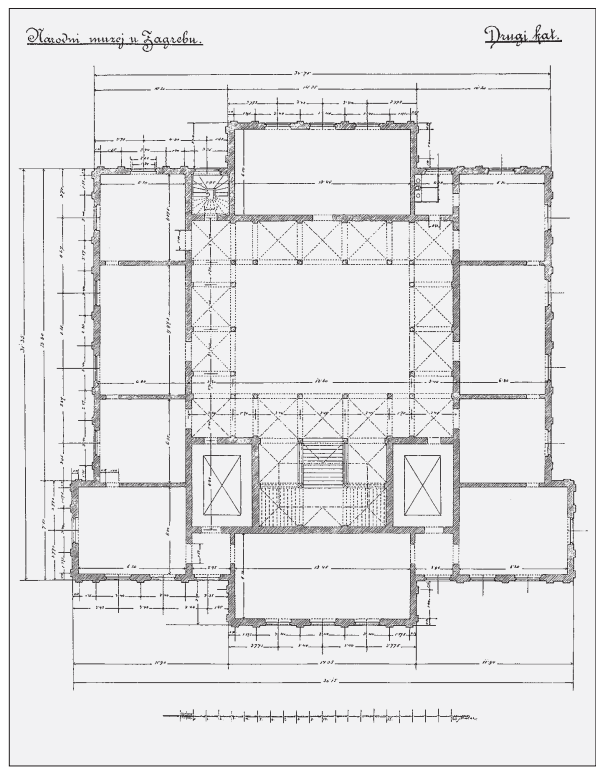



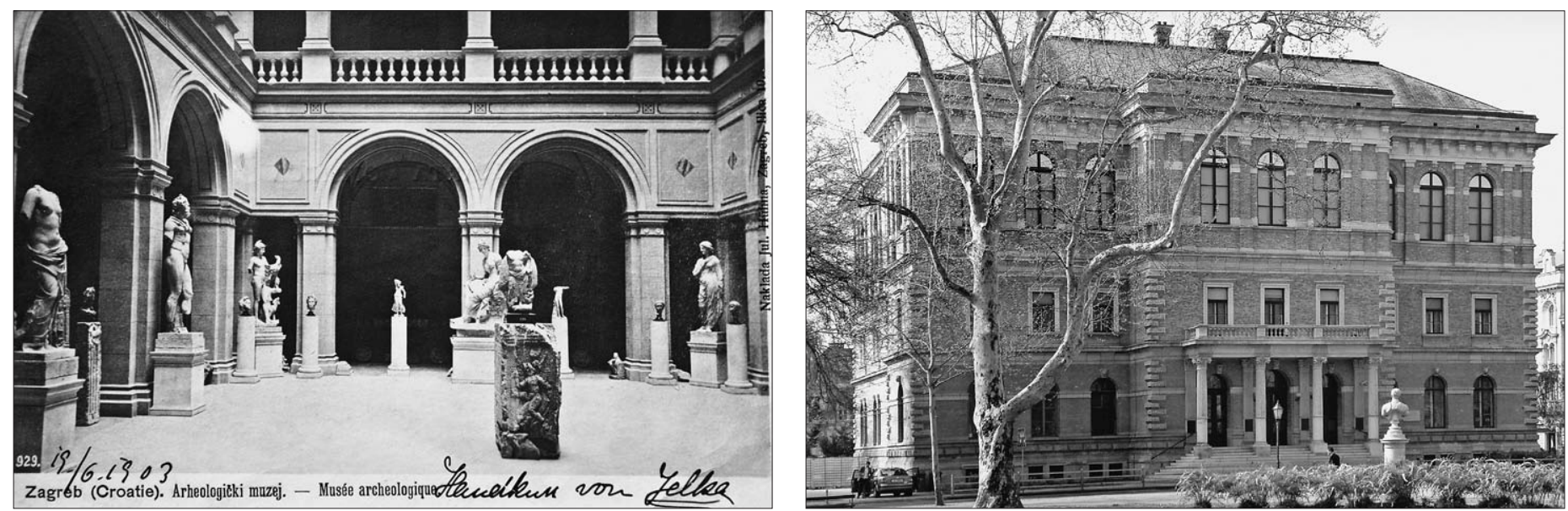

SL. 27. Prizemlje atrija palaće HaZU dok Se u nJemu NALAZIO ARHEOLOŚKI ODJEL NARODNOGA MUZEJA, OKO 1903.

FIG. 27 GROUND-FLOOR LEVEL OF THE PALACE ATRIUM IN THE CROATIAN ACADEMY OF SCIENCES AND ARTS AT THE TIME WHEN IT HOUSED THE ARCHAEOLOGICAL DEPARTMENT of the national Museum, ARound 1903

\section{SL. 28. PALAČA HAZU, DANAŠNJI IZGLED}

FIg. 28 CRoAtian ACADEMy OF SCIENCES AND ARTS, THE PALACE NOWADAYS

SL. 29. SREDIŠNJI PROSTOR PALAČE HAZU Fig. 29 CROATIAN ACADEMY OF SCIENCES AND ARTS, CENTRAL AREA OF THE PALACE

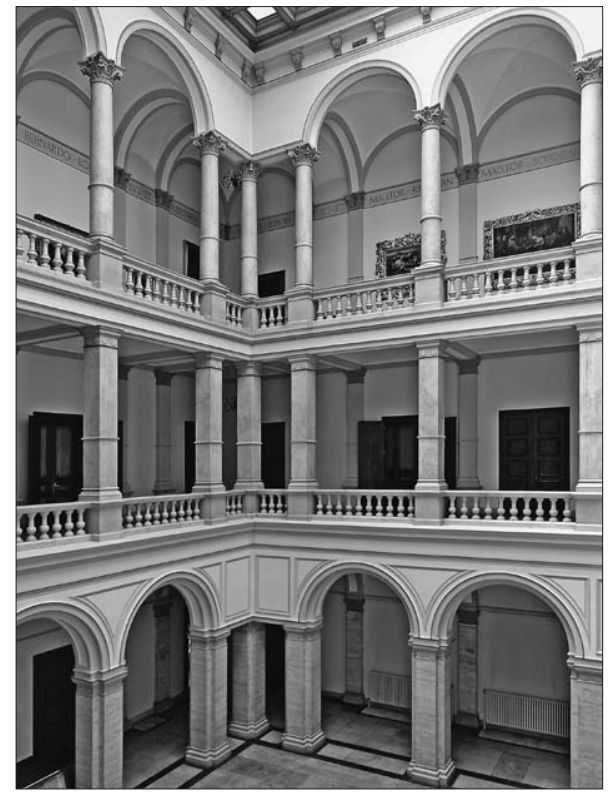

Kako je Strossmayer i dalje inzistirao „da se monumentalna zgrada gradi” ${ }^{116}$, od projekta se nije odustalo, vec se pristupilo daljnjem skupljanju sredstava. I sam je biskup darovao dodatnih 20.000 forinti, pa je uz ovaj novac, pomoc vlade i zajmove koje je dignula Akademija naposljetku zgrada uspjela biti podignuta.

U izvedbeni projekt za palaču Schmidt je unio dodatne promjene $\mathrm{u}$ odnosu na projekt s početka 1877., osobito u rješenju prizemlja (SI. 19.). Prizemlje je povišeno, nesumnjivo kako bi se vecim prozorima osigurala bolja osvijetljenost prostorija Arheološkog odjela. ${ }^{117} \mathrm{Na}$ dalje, trijem u rizalitno istaknutom središnjem dijelu pročelja ponešto je pojednostavljen - Schmidt je odustao od izvedbe i punih stupova i pilastara na uglovima rizalita te se odlučio za postavljanje rustike, kao i na prvome katu. Odustao je, nadalje, od postavljanja grbova na rubnim dijelovima rizalita, od nosača baklji na rubovima pročelja te od ograde od kovanoga željeza na terasi iznad trijema, a odlučio se umjesto toga za kamene balustrade. Po izvedbenom je projektu promijenjen i izgled prozora u podrumu Akademije. Umjesto izduženih, Schmidt se odlučio za kvadratične, nešto veće prozore. Nadalje, na zidovima prvoga kata promijenio je rješenje prozora (odustao je od izvedbe segmentnih lukova od opeka), ojačao je rustiku na uglovima, a na drugome katu odustao je od ploča s natpisima na rubnim dijelovima rizalitno istaknutog dijela pročelja (SI. 20.-21.)

lako je i za prvu varijantu trecega projekta Kršnjavi istaknuo da je „Plan reduciran [...] što se dekoracije tiče na minimum, još niže se ne može ići ako hoćemo imati monumentalnu sgradu" ${ }^{118}$, Schmidt je ipak učinio dodatnu redukciju u dekoraciji.

Kršnjavi je prigovarao i proporcijama zgrade, pa je moguce da je stoga izvedbeni projekt predvidio nešto širu građevinu u odnosu na prvu varijantu trećega projekta s početka
1877. „Meni se čini da je širina sgrade na visinu, premalena. 'Axenweite' bi se samo povecanjem troška povećati mogao, nek indi Schmidt na drugi način to popravi. Da me moje estetično čuvstvo ne vara dokazuje to, što je sgrada za kat povišena, a ostala je jednako duga kao i prije. Učinio sam gg. Arhitektom tu primetbu, ali su ta gospoda ponješto svoje glave, pa ne priznaju rado da su pogriešili. Bollé mi je doduše rekao da će se façada za koju stopu raširiti nu ja mislim da bi trebalo više da se postigne liepo razmjerje sa visinom." ${ }^{119}$ Arhitekti, međutim, nisu uvažili njegovu dodatnu primjedbu „da su prozori preblizu jedan drugomu. To niti je liepo niti za razredanje slika probitačno. Osobito mi se čini ružno da je uz srednji trakt prozor ko pritisnut. Razširi li se façada dat ce se lahko i prozori razmaknuti ponješto, pa makar po dva pilastera došla medju prozore mjesto jednoga". ${ }^{20}$ Povećanje prozora zasigurno bi iziskivalo vece promjene projekta, na što Schmidt i Bollé, nakon svih dotadašnjih promjena, više nisu bili spremni. Arhitekti su, međutim, prihvatili sugestije Kršnjavoga da dio prostorija u Galeriji ima prozore na krovu, kao i da se na tavanu (u mansardi) osigura prostor za slikare. ${ }^{121}$

116 ŠıŠıc, 1929: 118, Strossmayer Račkom, Rogatac, 17.7. 1877.

117 Arheološki odjel Narodnog muzeja u prizemlju je našao mjesto, čini se, po żelji Franje Račkoga jer se radilo o instituciji koja je bila odvojena od Akademije i Strossmayerove galerije slika [HR-HDA-804, KI, kut. 4, III/2, Rački Kršnjavom, Zagreb, 11.12.1876.; DuLIBIĆ, PASINI TRŻEC, 2018: 280]

118 HR-AHAZU, XII A 332/20, Kršnjavi Račkom, 13.2.1877. 119 HR-AHAZU, XII A 332/20, Kršnjavi Račkom, 13.2.1877. 120 HR-AHAZU, XII A 332/20, Kršnjavi Račkom, 13.2.1877. 121 HR-AHAZU, XII A 332/20, Kršnjavi Račkom, 13.2.1877. 122 STROSSMAYER, 1875.f: 91

123 StrossmaYer, 1879: 58

124 HR-AHAZU, XII A 332/20, Kršnjavi Raćkom, Beć, 13.2.1877.

125 KNOLL, 1922: 9 
U organizaciji prostora između projek(a)ta iz veljače i svibnja/lipnja 1877. također ima stanovitih razlika, ali one nisu jako velike. Neuobičajena odlika izvedbenog projekta u organizaciji prostora, koja se poslije veoma isticala, predstavlja smještaj stubišta (SI. 22.-23.) koje je postavljeno u stranu od glavnog ulaza da se omoguci fizička odvojenost Arheološkog odjela od ostalih institucija smještenih u palači (SI. 24.-26.). Središnji prostor, kao i na prethodnim projektima, cini staklom natkriven atrij. Izvorno je unutrašnjost zgrade bila dekorativno oslikana, no poslije su modernizacije, na żalost, uklonile ovaj važni sloj izvorne raščlambe (SI. 27., 29.).

Glavna karakteristika pročelja prema trecem projektu svakako je upotreba fasadne opeke kao glavnoga materijala (SI. 28.). Od velikih površina prekrivenih kamenom odustalo se radi uštede. Daleko bi se više uštedjelo da se pribjeglo izvedbi žbukanih pročelja, ali to su odbacili i biskup Strossmayer i Iso Kršnjavi. Biskup je smatrao, naime, oduševljen berlinskim i minhenskim javnim građevinama podignutim s pročeljima od fasadne opeke (osobito berlinskom vijecnicom i takozvanom vladinom zgradom u Münchenu), da se takav tip gradnje treba prenijeti i u javnu i stambenu arhitekturu Hrvatske: „U nas u Zagrebu i Osieku prave se vrlo dobre opeke, pak da je dovoljno znanja architektoničkoga, da je dobrih poznavalaca i risara uresa architekturalnih, da je kapitala i obrtničke okretnosti, lahko bi se mogli i u nas, barem u Zagrebu i Osieku, proizvadjati ti detailli, uresi, itd. na veliku našu korist i na ukrašenje naših varoša i domova." ${ }^{122}$ Uostalom, i svoju je katedralu podigao $s$ tim tipom pročelja, obično zvanim u to doba Rohbau. Bio je protivnik primjene skrivanja na pročeljima od kojeg se materijala zgrada gradi, osobito u slučaju vecih građevina. „Fikcija se nepristoji sgradi monumentalnoj." "123

Ta su se Strossmayerova razmišljanja izvrsno nadovezala na razmišljanja Ise Kršnjavoga koji je krajem 1870-ih i početkom 1880-ih poveo pravu borbu za uvođenje Rohbau pročelja u hrvatsku arhitekturu. Kršnjavi je dapače tvrdio da je upravo on nagovorio Schmidta da koristi fasadnu opeku kao osnovni materijal pročelja palače Akademije: „Hvala Bogu, da sam teda negda Schmidta na čisti Zegelrohbau sklonuo. Što je trošak pri gradnji možda malo veci, to se prištedjuje tim što ne treba svaki čas popravka, čišcenja, etc., a monumentalnost sgrade točno ondje prestaje gdje Verputz počima. Tko ne može sagraditi sasvim iz kamena, taj neka to pošteno i prizna, pa nek ciglom zida, ali neka toga nikakvim tutkalom ne sakrije. Poštenje je i u estetici važno načelo!”124

Bez obzira na to jesu li Strossmayerove želje ili preporuke Kršnjavoga odigrale ključnu ulogu u odabiru materijala, nesumnjivo je da ce rješenje pročelja palače Akademije imati snažan utjecaj na zagrebačku arhitekturu krajem 1870-ih i početkom 1880-ih, kada ce u gradu biti realizirano nekoliko zanimljivih pročelja izvedenih od toga materijala (Bolléove kurije na Kaptolu i u Novoj Vesi, djelomično mirogojske arkade, zgrada Sokola). Utjecaj ce, doduše, biti kratkotrajan, jer ce na kraju ipak prevladati tradicija žbukanih pročelja.

\section{ZAKLJUČNE RIJEČI - PALAČA HAZU I JAVNA ARHITEKTURA HRVATSKE 1870-IH I POČETKOM 1880-IH}

\section{CONCLUDING REMARIS - THE PALACE OF THE CROATIAN ACADEMY OF SCIENCES AND ARTS AND THE CROATIAN PUBLIC ARCHITECTURE OF THE 1870 S AND THE EARLY 1880 S}

Nakon godina pripreme palača Akademije konačno je izgrađena od kolovoza 1877. do ljeta 1880., tako da je u njoj prva sjednica Akademije mogla biti održana 11. 10. 1880. godine. ${ }^{125}$ Potres koji ce mjesec dana poslije pogoditi Zagreb produžit ce proces daljnjega useljavanja u zgradu. Institucija zbog koje je Strossmayer i započeo cijeli projekt - Galerija njegovih slika - bit ce stoga otvorena na prvome katu zgrade tek 9. 11. 1884., na trecu obljetnicu zagrebačkoga potresa te devet $\mathrm{i}$ pol godina nakon darovnice kojom je biskup svoju zbirku, zajedno s 40.000 forinti, darovao Akademiji i Zagrebu. S čovjekom zbog kojega je pokrenuo cijeli projekt, Isom Kršnjavim, prvim ravnateljem Galerije, biskup je u to vrijeme zbog političkih razloga već prekinuo suradnju.

Razočaran situacijom u Hrvatskoj Strossmayer ce se od tada početi sve više povlačiti, i to ne samo iz političkog već i kulturnog života zemlje. Djelima koja je realizirao tijekom 1860-ih i 1870-ih, pokazat ce se s vremenom, postigao je, međutim, ono što je želio - pokrenuo je svojevrsnu renesansu hrvatske umjetnosti.

\section{LITERATURA}

\section{BIBLIOGRAPHY}

1. Anderson, E. (2015.), Jakob von Falke und der Geschmack, u: Klimt und die Ringstrasse [ur. Husslein-Arco, A.; KleE, A.], Belvedere: 23-33, Beč

2. Bolzoni, L.; PAyne, A. (2018.), Introduction, u: The Italian Renaissance in the $19^{\text {th }}$ Century. Revision, Revival, and Return [ur. BolzoNI, L.; PAyne, A.], I Tatti Research Series 1: 9-17, Firenca, Milano

3. BurCKHARDT, J. (1860.), Die Cultur der Renaissance in Italien: ein Versuch, Schweighauser, Basel

4. Burckhardt, J. (1868.), Geschichte der Renais sance in Italien, Ebner\&Seubert, Stuttgart

5. BurCKHARDT, J. (1912.), Geschichte der Renaissance in Italien, Paul Neff Verlag (Max Schreiber), Eszlingen a. N.

6. Buttlar, A. von (2014.), Leo von Klenze. Leben. Werk. Vision, Verlag C.H. Beck, München

7. Cvitanovic, Đ. (1978.), Arhitektura monumentalnog historicizma u urbanizmu Zagreba, „Život umjetnosti”, 26-27: 127-160, Zagreb

8. Damjanovic, D. (2008.), Iso Kršnjavi i opremanje đakovacke katedrale, Zbornik Odsjeka za povijesne znanosti Zavoda za povijesne i društvene znanosti HAZU, 26: 195-219, Zagreb

9. DAMJANOvic, D. (2009.a), Dakovačka katedrala, Matica hrvatska, Zagreb

10. Damjanović, D. (2009.b), Herman Bollé - izgradnja i opremanje katedrale u Dakovu (1876. 1884.), „Croatica Christiana periodica”, 33 (63): 109-127, Zagreb

11. Damjanovic, D. (2013.), Arhitekt Herman Bollé, Leykam international, Muzej za umjetnost i obrt, Zagreb

12. Dobronic, L. (1983.), Graditelji i izgradnja Zagreba u doba historijskih stilova, Društvo povjesničara umjetnosti SR Hrvatske, knjiga XXX, Zagreb

13. Dulibic, L.; PASINI TRŻeC, I. (2013.), Strossmayerova galerija starih majstora Hrvatske akademije znanosti i umjetnosti i 'njezina' zgrada, u: Muzeji i arhitektura u Hrvatskoj. Zbornik 2. kongresa hrvatskih muzealaca [ur. GALJER, J.], Hrvatsko muzejsko društvo: 34-41, Zagreb

14. Dulibić, L.; PAsinı Tržec, I. (2018.), Strossmayerova zbirka starih majstora, HAZU, Zagreb

15. Eitelberger von Edelberg, R. (1879.), Gesammelte kunsthistorische Schriften, II. Band. Oesterreichische Kunst - Institute und Kunstgewerbliche Zeitfragen, Wilhelm Braumüller: 370-404, Bec

16. HAIKO, P.; KASSAL-MIKULA, R. (1991.), Friedrich von Schmidt (1825-1891). Ein gothischer Rationalist, Historisches Museum der Stadt Wien, Beč

17. Horvat, R. (1898.), Akademijska palača, „Prosvjeta”, 6 (15.3.): 180-184, Zagreb 


\section{|ZVORI}

\section{SOURCES}

18. Horvat, R. (1925.), Akademijska palača u Zagrebu, u: Stari i novi Zagreb. Historičke i kulturno-historicke crtice o Zagrebu [ur. LAszowSKI, E.], Braca hrvatskog zmaja: 214-227, Zagreb

19. Jašo, M.; PaIć-VuKıć, T. (2011.), Osnivanje $i$ počeci rada Akademije u dokumentima Arhiva HAZU, HAZU, Zagreb

20. KNEŻEVIć, S. (1994.), Akademijina palača i njezini trgovi, „Bulletin Razreda za likovne umjetnosti HAZU", 1 (60): 35-46, Zagreb

21. KNEŽEVIĆ, S. (1995.), Zagrebačka zelena potko$v a$, Školska knjiga, FS, Zagreb

22. KRŠnjavi, I. (1875.), Gdje da gradimo galeriju?, „Obzor”, 149 (3.7.): 1, Zagreb

23. KRŚnjavI, I. (1917.), Povijest gradnje akademske palace, „Savremenik”, XII: 166-171, Zagreb

24. KNolL, P. (1922.), Akademijska galerija Strossmayerova, Jugoslavenska akademija znanosti i umjetnosti, Zagreb

25. LeVINE, N. (2018.), The Unexpected Fate of the Italian Renaissance in Nineteenth-Century French Architecture, u: The Italian Renaissance in the $19^{\text {th }}$ Century. Revision, Revival, and Return [ur. BolzonI, L.; PAYNe, A.], I Tatti Research Series 1: 491-508, Firenca, Milano

26. MARoević, I. (1968.), Graditeljska obitelj Grahor, Društvo historičara umjetnosti Hrvatske, knjiga XV., Zagreb

27. MARTINČIĆ, I. (2007.), Planoteka kabineta za arhitekturu i urbanizam Hrvatske akademije znanosti i umjetnosti, HAZU, Zagreb

28. MARUŠEVSKI, O. (1986.), Iso Krśnjavi kao graditelj: izgradnja i obnova obrazovnih, kulturnih i umjetničkih objekata u Hrvatskoj, Društvo povjesničara umjetnosti SR Hrvatske, knjiga 37, Zagreb

29. Mennekes, R. (2005.), Die Renaissance der deutschen Renaissance, Michael Imhof Verlag, Petersberg

30. Popovčak, B.; Vandura, D. [ur.] (2006.), Strossmayerova donacija. Europska umjetnost od $X$. do XIX. stoljeca, HAZU, Strossmayerova galerija starih majstora, Zagreb

31. SMIČIIKLAS, T. (1906.), Nacrt żivota i djela biskupa J. J. Strossmayera; I. Izabrani njegovi spisi: govori, rasprave i okrużnice, JAZU, Zagreb

32. Strossmayer, J.J. (1874.a), Druga slika u našoj novoj stolnoj crkvi, I., „Glasnik Biskupija bosanske i sriemske" (dalje u popisu literature samo Glasnik), 1 (15.1.): 5-7, Đakovo

33. Strossmayer, J.J. (1874.b), Stolna crkva djakovačka, III., „Glasnik”, 7 (15.4.): 55-56, Dakovo

34. Strossmayer, J.J. (1874.c), Stolna crkva djakovačka, V., „Glasnik”, 9 (15.5.): 70-72, Dakovo

35. Strossmayer, J.J. (1874.d), Stolna crkva djakovačka, VI., „Glasnik”, 10 (31.5.): 77-79, Dakovo

36. Strossmayer, J.J. (1874.e), Stolna crkva djakovačka, XI., „Glasnik”, 15 (15.8.): 117-119, Dakovo
37. Strossmayer, J.J. (1874.f), Stolna crkva djakovacka, XIV., „Glasnik”, 18 (30.9.): 141-144, Dakovo

38. Strossmayer, J.J. (1874.g), Nekoliko rieči o stolnoj crkvi zagrebaćkoj, „Katolički list”, 36 (3.9.): 1-8 (Prilog), Zagreb

39. Strossmayer, J.J. (1875.a), Putopisne crtice, I., „Glasnik”, 2 (31.1.): 12-14, Đakovo

40. Strossmayer, J.J. (1875.b), Putopisne crtice, II., "Glasnik", 3 (15.2.): 28-30, Dakovo

41. Strossmayer, J.J. (1875.c), Putopisne crtice, III., „Glasnik”, 5 (15.3.): 50-53, Dakovo

42. Strossmayer, J.J. (1875.d), Putopisne crtice, VI., „Glasnik”, 8 (30.4.): 75-78, Dakovo

43. Strossmayer, J.J. (1875.e), Putopisne crtice, VII., „Glasnik”, 9 (15.5.): 83-85, Dakovo

44. Strossmayer, J.J. (1875.f), Putopisne crtice, VIII., „Glasnik”, 10 (31.5.): 89-91, Dakovo

45. Strossmayer, J.J. (1875.g), Putopisne crtice, XI., „Glasnik”, 13 (15.7.): 115-116, Dakovo

46. Strossmayer, J.J. (1875.h), Putopisne crtice, XII, „Glasnik”, 14 (31.7.): 122-124, Dakovo

47. Strossmayer, J.J. (1877.a), Misli o nasih prosvjetnih zavodih, „Obzor”, 291 (20.12.): 1-2, Zagreb

48. Strossmayer, J.J. (1877.b), Misli o naših prosvjetnih zavodih, „Obzor”, 293 (22.12.): 1, Zagreb

49. Strossmayer, J.J. (1879.), Velecienjeni prijatelju, „Glasnik”, 6 (31.3.): 57-59, Dakovo

50. Šıšıć, F. (1928.), Korespondencija Rački-Strossmayer, Knjiga I., JAZU, Zagreb

51. Šıšıć, F. (1929.), Korespondencija Rački-Strossmayer, Knjiga II., JAZU, Zagreb

52. Tartaglia Kelemen, V. (1973.), Pisma Izidora Kršnjavoga 1874.-1878., „Radovi arhiva JAZU”, II: 157-220, Zagreb

53. Wagner-Rieger, R. (1970.), Wiens Architektur im 19. Jahrhundert, Österr. Bundesverl. für Un terricht, Wiss. u. Kunst, Beč

54. *** (1875.), Darovnica za zgradu galerije, „Obzor", 75 (3.4.): 1, Zagreb

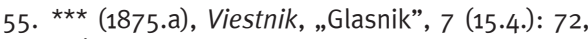
Dakovo

56. *** (1875.b), Njegova Preuzvišenost g. Biskup Strossmayer u Zagrebu, „Obzor”, 168 (26.7.): 3, Zagreb

57. *** (1876.), O galeriji slika, „Vienac”, 8/15 (18.4.): 256, Zagreb

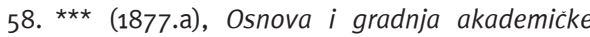
palace, „Obzor”, 47 (27.2.): 3, Zagreb

59. *** (1877.b), Gradjevna osnova za akademičku palaču, „Obzor”, 128 (6.6.): 3, Zagreb

6o. *** (1877.c), Gradj. nadsavjetnik g. Schmidt, „Obzor", 159 (13.7.): 4, Zagreb
ARHIVSKI IZVORI

ARCHIVE SOURCES

1. Arhiv Hrvatske akademije znanosti i umjetnosti, Zagreb [HR-AHAZU]

2. Hrvatski državni arhiv, fond br. 78 , Predsjedništvo Zemaljske vlade [HR-HDA-78, PRZV]

3. Hrvatski državni arhiv, fond br. 804, Kršnjavi, Isidor [HR-HDA-804, KI]

4. Kabinet za arhitekturu i urbanizam Hrvatske akademije znanosti i umjetnosti [KAU HAZU]

5. Nadbiskupijski arhiv u Dakovu, Crkveni građevni odbor (spisi vezani za gradnju đakovačke katedrale) [NAD, CGO]

6. Nadbiskupijski arhiv u Zagrebu, Dijecezanski muzej, Zbirka građevnih nacrta [HR-NAZ, DM, ZGN]

7. Wienmuseum, HM, Inv. Nr. 157.080/1-30 (projekti Friedricha Schmidta za palaču Akademije u Zagrebu)

IZVORI ILUSTRACIJA

ILLUSTRATION SOURCES

SL. 1., 15.-17. Z Zbirka g. Jure Gašparca, Zagreb SL. 2.-11.,

13., 14., 18. Wienmuseum, HM, Inv. Nr. 157.080 SL. 12., 24.-25. HR-NAZ, DM, ZGN, sign III-33

SL. 19., 23., 26. HR-AHAZU, fototeka V-23

SL. 20.-22. KAU HAZU

SL. 27. Zbirka razglednica mr.sc. Ivana Bo-

gavčića

SL. 28. Foto: autor, 19.4.2010.

SL. $29 . \quad$ Foto: autor, 14.5.2013. 


\title{
SAŽETAK
}

\author{
SUMMARY
}

\section{Designing the Palace of the Croatian Academy of Sciences and Arts IN ZAGREB (1875-1877)}

\section{Renaissance of the Renaissance in Croatian Architecture}

The central palace of the Yugoslav (today Croatian) Academy of Sciences and Arts, situated on Nikola Subic Zrinski square in Zagreb, is one of the outstanding Historicist public buildings in Croatia. This monumental edifice greatly contributed to the urbanization of the city area where it was built the eastern side of the so-called Zagreb's Green Horseshoe. In terms of its architectural concept, it is undoubtedly one of the first High Historicist buildings of Croatian architecture.

Several people deserve full credit for its construction: bishop Josip Juraj Strossmayer from Dakovo, canon of the Archdiocese of Zagreb, Franjo Racki historian and president of the Academy, Iso Kršnjavi - the first Croatian art historian, and the architects Friedrich Schmidt and Herman Bollé. This article attempts to show how bishop Strossmayer developed his idea about the palace design and to analyze the unknown design versions elaborated by the architect Friedrich Schmidt. They are preserved in the Viennese City Museum (Wienmuseum) as a part of his architectural legacy and in a private collection in Zagreb. This research has shown that Schmidt had produced at least three designs for the palace (some in different versions) before he produced the final detailed technical design.

The idea of building a palace was born in Rome in 1875 when bishop Strossmayer and Iso Kršnjavi started their long-standing friendship. They both clearly saw the need to build a palace in order to accommodate the offices of the Yugoslav Academy of Sciences and Arts and house a great collection of bishop Strossmayer's paintings that he decided to donate to the Academy with the aim to "to improve good taste in art" in Croatia. Delighted with Kršnjavi, bishop then decided to support Kršnjavi's nomination for professorship at the University of Zagreb and forge close links between the newly established Department of Art History and his Gallery of Paintings.

Upon his return to Croatia from Rome on March 26, 1875. Strossmayer gave a generous donation to the Academy: his collection of paintings and 40 ooo forints (a substantial sum of money at the time) to support the palace construction. Together with Franjo Rački he started an intensive campaign to persuade the Croatian government (headed by the governor Ivan Mażuranic) and the city authorities of Zagreb (headed by the mayor Ivan Voncina) to support the whole project by granting funds and an appropriate lot for the palace.

Strongly influenced by contemporary tendencies in architecture of the period and especially by the museum buildings he saw on his trips to Central Europe (Pinakoteka in Munich by Leo von Klenze, The Old Masters Dresden gallery designed by Gottfried von Semper, and the Austrian Museum of Art and Industry in Vienna by Heinrich Ferstel), Strossmayer chose Renaissance as an appropriate style for the palace. In view of the fact that the great masters of this style in Vienna were Theophil von Hansen and Heinrich Ferstel, Strossmayer intended to offer the commission to one of these two architects but in the end he opted for Friedrich Schmidt. Bishop knew Schmidt very well since this architect was working simultaneously on the completion of Strossmayer's cathedral in Dakovo and the restoration of St. Mark's parish church in Zagreb (again on Strossmayer's initiative).

Schmidt decided that Italian Renaissance would be an appropriate style for the palace due to the physiognomy of the Zagreb City and the character of Strossmayer's collection of paintings consisting of predominantly Italian masters of the 15th and 16th century. His first design for the palace was completed in summer 1875 . He envisaged a two-storey building on tall substructures. The ground-floor level was designed to accommodate the offices of the Academy while the first floor was intended for the Gallery of paintings and a state-room.

The first design was specifically adapted to the site, i.e. the lot on the southeastern edge of the Upper town, the plateau on Gric donated by the City of Zagreb in April 1875 as the appropriate site for the Academy palace. However, some representatives from the Zagreb City Assembly fiercely opposed it because they feared that Zagreb would lose its most beautiful promenade. In early 1876 the City decided to offer a more adequate site for this building - Nikola Śubic Zrinski square in Lower town. Accordingly, Schmidt was commissioned to pro- duce a new design for the palace. His assistant at the time, Herman Bollé, who later became a leading figure of the Croatian Historicist architecture, started to work with him on the new project.

The second design for the Academy palace and the gallery of paintings was completed until August 1876. The building was again conceived as a twostorey structure, yet with entirely different proportions in comparison with the building from the 1875 design. The ground-floor level was designed to accommodate the Academy's offices and the library while the first floor was intended to house the Gallery of paintings following the first project. In order to provide enough daylight, the first floor level was equipped with big arched windows.

But this project was not realized either. The Croatian government was willing to donate 80000 forints on condition that the palace houses the $\mathrm{Ar}$ chaeological Department of the National Museum. Schmidt (again in collaboration with Bollé) produced the third design version in February 1877. It was approved both by the Academy and the Croatian government with a request for some minor changes such as a modified spatial organization and a more simplified design of the main facade. After Schmidt had completed detailed technical drawings in May/June 1877, construction started in August the same year. The palace was finally built as a two-storey building. The ground-floor level accommodated the Archaeological Department of the National Museum, while the offices, the library and the archive of the Yugoslav Academy of Sciences and Arts were placed on the first-floor. The second-floor housed bishop Strossmayer's Gallery of paintings. The palace was built in Italian Renaissance style with brick facades and partly stone facade cladding. The building was completed in summer 1880. However, the Gallery of paintings was not opened until November 11,1884 , due to the earthquake on November 9, 1880, which did serious damage to the building.

As bishop Strossmayer hoped, the Academy palace set new standards for monumental buildings in the central Zagreb area as well as for other public buildings built on the so-called Green Horseshoe line.

\section{BIOgRAFIJA}

\section{BIOGRAPHY}

Dr.sc. DRagan Damjanović rođen je 1978. u Osijeku. Izvanredni je profesor na Odsjeku za povijest umjetnosti Filozofskoga fakulteta Sveučilišta u Zagrebu, na kojem radi od 2003. Glavni mu je interes vezan za povijest hrvatske arhitekture 19. i 20. stoljeca. Voditelj je projekta Hrvatske zaklade za znanost „Umjetnost i država u Hrvatskoj od prosvjetiteljstva do danas" (od 2018. godine).
Dragan Damjanović, Ph.D., Associate Professor, born in 1978 in Osijek. He has been employed in the Department of Art History at the Faculty of Humanities and Social Sciences University of Zagreb since 2003. Since 2018 he has been head of the project "Art and the State in Croatia from the Enlightenment to the Present" financed by the Croatian Science Foundation. 


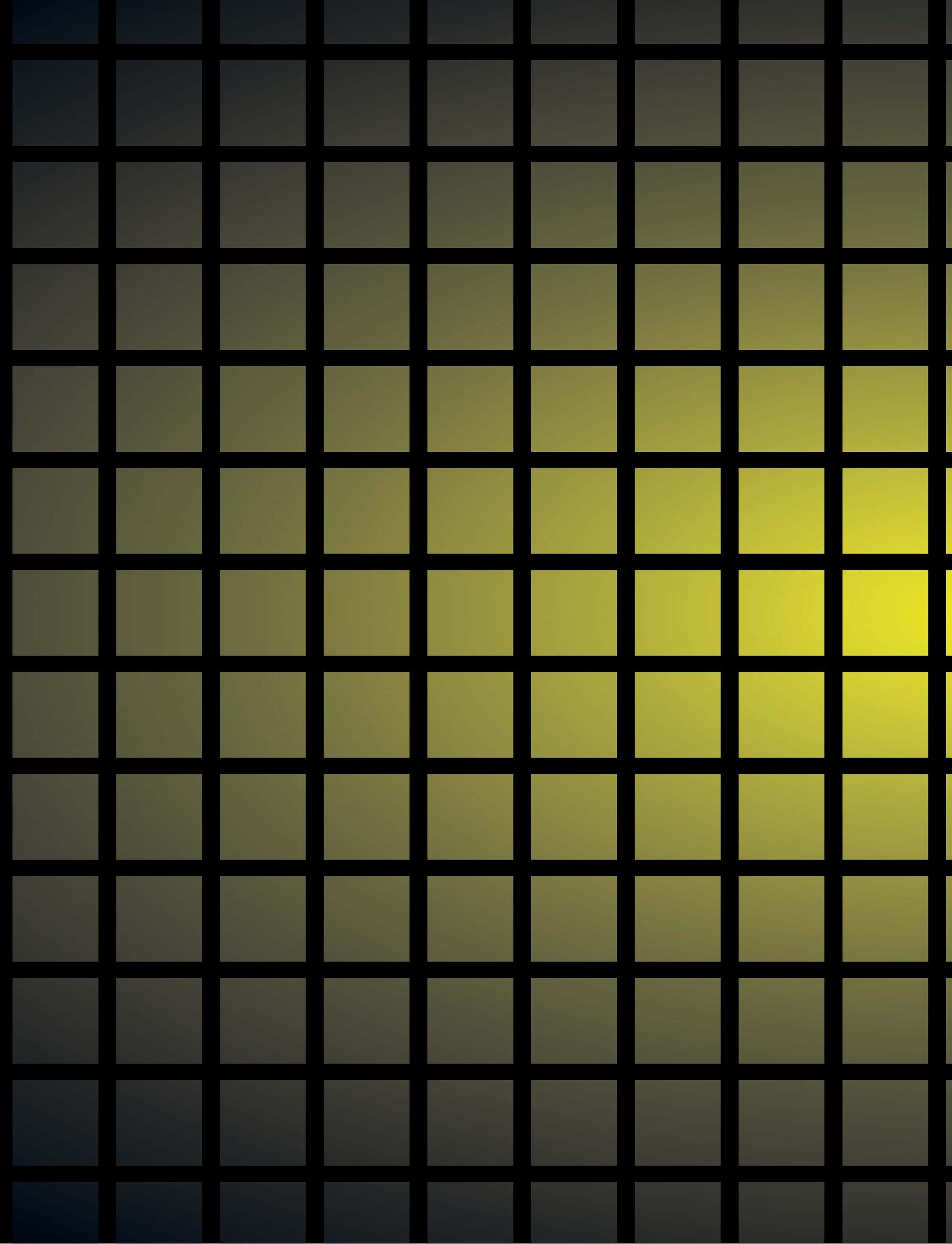

